\title{
Characteristics of bacterial community in cloud water at Mt Tai: similarity and disparity under polluted and non-polluted cloud episodes
}

\author{
Min Wei ${ }^{1}$, Caihong $\mathrm{Xu}^{1}$, Jianmin Chen ${ }^{1,2}$, Chao $\mathrm{Zhu}^{1}$, Jiarong $\mathbf{L i}^{1}$, and Ganglin $\mathbf{L v}^{1}$ \\ ${ }^{1}$ Environment Research Institute, School of Environmental Science and Engineering, Shandong University, \\ Jinan 250100, China \\ ${ }^{2}$ Shanghai Key Laboratory of Atmospheric Particle Pollution and Prevention (LAP), Fudan Tyndall Centre, \\ Department of Environmental Science \& Engineering, Fudan University, Shanghai 200433, China
}

Correspondence to: Jianmin Chen (jmchen@sdu.edu.cn)

Received: 29 August 2016 - Discussion started: 20 September 2016

Revised: 10 March 2017 - Accepted: 19 March 2017 - Published: 24 April 2017

\begin{abstract}
Bacteria are widely distributed in atmospheric aerosols and are indispensable components of clouds, playing an important role in the atmospheric hydrological cycle. However, limited information is available about the bacterial community structure and function, especially for the increasing air pollution in the North China Plain. Here, we present a comprehensive characterization of bacterial community composition, function, variation, and environmental influence for cloud water collected at Mt Tai from 24 July to 23 August 2014. Using Miseq 16S rRNA gene sequencing, the highly diverse bacterial community in cloud water and the predominant phyla of Proteobacteria, Bacteroidetes, Cyanobacteria, and Firmicutes were investigated. Bacteria that survive at low temperature, radiation, and poor nutrient conditions were found in cloud water, suggesting adaption to an extreme environment. The bacterial gene functions predicted from the 16S rRNA gene using the Phylogenetic Investigation of Communities by Reconstruction of Unobserved States (PICRUSt) suggested that the pathways related to metabolism and disease infections were significantly correlated with the predominant genera. The abundant genera Acinetobacter, Stenotrophomonas, Pseudomonas, and Empedobacter originated from a wide range of habitats including cloud condensation nuclei and ice nuclei active species, opportunistic pathogens, and functional species, demonstrating the importance of ecology and health in cloud water. Cluster analysis including hierarchical cluster (Hcluster) and princi-
\end{abstract}

pal coordinate analysis $(\mathrm{PCoA})$ indicated a significant disparity between polluted and non-polluted samples. Linear discriminant analysis effect size (LEfSe) demonstrated that potential pathogens were enriched in the polluted cloud samples, whereas the diverse ecological function groups were significant in the non-polluted samples. Discrepant community structure determined by redundancy analysis (RDA) indicated that the major ions in cloud water and $\mathrm{PM}_{2.5}$ in the atmosphere have a negative impact on bacteria, playing a vital role in shaping microbial community structure. The major ions might provide nutrition to bacteria and directly influence the bacterial community, whereas $\mathrm{PM}_{2.5}$ in air has an indirect impact on bacterial community structure. During wet deposition, soluble particulate matter was dissolved in water droplets resulting in elevated concentration in cloud water. $\mathrm{PM}_{2.5}$ was possibly associated with different origins and pathways of air mass as determined using source tracking by the backward trajectory, mainly related to long-range transport. This work enhanced our understanding of the characteristics of bacterial ecology in the atmospheric aqueous phase, highlighting the potential influence of environmental variables on the bacterial community in cloud processes. It may provide fundamental information of the bacterial community response in cloud water under increasing pollution. However, due to the limited sample size (13 samples) collected at the summit of Mt Tai, these issues need in-depth discussion. Further studies based on an annual series of field 
observation experiments and laboratory simulations will continue to track these issues.

\section{Introduction}

Clouds are an aerosol system composed of tiny droplets suspended in the atmosphere. In the atmosphere, pollutants attached to particles can be dissolved or incorporated into cloud droplets, which may have complex effects on environment security and human health. Over the past decades, studies on cloud water have mainly focused on the physical and chemical properties (Aikawa et al., 2001; Boris et al., 2016; Fernández-González et al., 2014). Recently, with the in-depth understanding of cloud characteristics, studies on bioaerosols have been on the rise.

Living microorganisms, including bacteria, fungi, and yeasts, have been shown to be present in clouds (Burrows et al., 2009). In the first study on biological particles in fog/cloud water, Fuzzi et al. (1997) suggested bacterial replication on foggy days. Later, with the development of detection techniques, microorganisms in fog/cloud water have been systematically studied (Amato et al., 2007c; Delort et al., 2010; Vaïtilingom et al., 2012). Combined with field investigations and laboratory experiments, diverse bacterial communities have been retrieved, and the bacterial metabolism active in cloud water has been further demonstrated. In the atmospheric aqueous phase, microorganisms can act as cloud condensation nuclei (CCN) and ice nuclei (IN), which have a potential impact on cloud formation and precipitation processes (Amato et al., 2015; Bauer et al., 2003; Mortazavi et al., 2015). Moreover, microorganisms in cloud water are available to metabolize organic carbon compounds (degrading organic acids, formate, acetate, lactate, and succinate) and are associated with carbon and nitrogen recycling (Amato et al., 2007a; Hill et al., 2007; Vaïtilingom et al., 2010). They can also influence photochemical reactions (Vaïtilingom et al., 2013) and participate in a series of complex biochemical metabolic activities.

Cloud occurrence is a complex process. In contaminated areas, clouds typically contain numerous pollutants such as sulfate and nitrate ions, organic carbon compounds, and bacteria (Badarinath et al., 2007; Després et al., 2012; Fernández-González et al., 2014; Mohan and Payra, 2009). As an intensive agricultural and economic region in China, the North China Plain has been affected by severe air pollution in recent years, for instance, the severe fog and haze pollution in Beijing and Jinan in January 2013 (Huang et al., 2014; Wang et al., 2014). Mt Tai $\left(36^{\circ} 15^{\prime} \mathrm{N}, 117^{\circ} 06^{\prime} \mathrm{E}\right.$; $1534 \mathrm{~m}$ a.s.1.), the highest mountain in the North China Plain, is frequently subject to cloud episodes (Guo et al., 2012; Liu et al., 2012). Emission and resuspension of bacteria by wind erosion or splashing water from various terrestrial environments into the atmosphere recruits diverse airborne bacte- ria, which possibly include pathogenic and functional bacteria. During the cloud formation process, these bacteria attached to particles or incorporated into cloud droplets will be deposited back to land via dry or wet deposition. Accumulation literature indicates that bacteria in cloud/fog water droplets have a potential effect on the diversity and function of atmospheric and terrestrial ecosystems (Delort et al., 2010; Vaitilingom et al., 2013), even inducing health risks through microbial pathogen dispersion (Vaïtilingom et al., 2012). Previous studies have examined the bacterial community in rain or snow (Cho and Jang, 2014; Mortazavi et al., 2015). They also focus on the bacteria associated with CNN/IN, potential pathogens, and biochemical reactions. Therefore, the evaluation of the potential ecologically functional bacteria in cloud water has been an urgent issue, especially for cloud water samples from polluted episodes.

Notably, atmospheric microorganisms are subject to a wide range of environmental conditions including meteorological factors and the physiochemical composition of aerosols (Womack et al., 2010). Community structure and function are closely related to the environmental characteristics in the atmosphere and the geomorphic characteristics (Dong et al., 2016; Gao et al., 2016). For instance, studies about inhalable bioaerosols suggest that environmental parameters including temperature, relative humidity, $\mathbf{P M}_{10}$, $\mathrm{PM}_{2.5}$, and particle size have a significant impact on the composition and dynamics of microbial communities (Adhikari et al., 2006; Bowers et al., 2013). However, owing to the paucity of detailed and comprehensive studies on atmospheric bacterial composition, our understanding of the bacterial community dynamics remains incomplete. During the polluted cloud process, the bacterial community variation and the decisive environmental factors are still scarcely studied.

In the present study, samples from typical cloud episodes under polluted and non-polluted weather conditions were collected on the summit of Mt Tai in the North China Plain. To understand the bacterial community structure and function, Miseq 16S rRNA gene sequencing was performed, and the Phylogenetic Investigation of Communities by Reconstruction of Unobserved States (PICRUSt) predictive function was applied to examine the metabolic and ecological function. Analysis of similarities (ANOSIM) and linear discriminant analysis effect size (LEfSe) were executed to clarify the discrepant bacterial taxa. Moreover, redundancy analysis (RDA) was applied to identify the pivotal environmental factors influencing the bacterial community. Air mass back trajectory was conducted to define the most likely source and transmission paths of the pollutants and bacteria. 


\section{Material and methods}

\subsection{Sample collection}

Cloud water samples were collected using the Caltech Active Strand Cloud Water Collector (CASCC) on the summit of Mt Tai $\left(36^{\circ} 15^{\prime} \mathrm{N}, 117^{\circ} 06^{\prime} \mathrm{E}\right.$; $1534 \mathrm{~m}$ a.s.l.). The collector was cleaned prior to each cloud event and kept closed prior to cloud interception to ensure that it was not contaminated. The collector was activated by a sensor only when cloud formed in the ambient air. Cloud water was aspirated through a Teflon duct at a rate of $24.5 \mathrm{~m}^{3} \mathrm{~min}^{-1}$ by a fan situated at the rear of collector. Water was collected from the Teflon strands, through a Teflon tube and down into Teflon bottles. The theoretical $50 \%$ cutoff size was equivalent to a drop diameter of $3.5 \mu \mathrm{m}$.

To avoid artificial and instrumental contamination, the Teflon tube and the polyethylene bottles were pretreated with anhydrous ethanol and washed three times using the sterilized ultrapure water. Before sampling, the collector was washed with the sterilized deionized distilled water filtered through $0.22 \mu \mathrm{m}$ membrane. The sterilized dd $-\mathrm{H}_{2} \mathrm{O}$ was sprayed into the collector and the collected water sample was considered to be the blank.

To distinguish the polluted and non-polluted cloud episodes, we firstly checked the air pollution condition according to the $24 \mathrm{~h}$ WHO air quality guideline $\left(\mathrm{PM}_{2.5}\right.$ concentrations, $25 \mu \mathrm{g} \mathrm{m}^{-3}$ ). This standard has been applied in Australia, New Zealand, and the European Union. A cloud episode with an average $\mathrm{PM}_{2.5}$ concentration higher than $25 \mu \mathrm{g} \mathrm{m}^{-3}$ was considered polluted. Further definition of cloud water was combined with the major ions in water droplets, which provide a deep insight into pollution levels. Therefore, in the present study, cloud episodes under high $\mathrm{PM}_{2.5}$ concentration and high-concentration ions in cloud water were classified as polluted episodes.

After adjustment, seven cloud episodes and 13 samples were obtained during the whole sampling period (from 24 July to 23 August 2014), including 11 polluted and 2 nonpolluted cloud water samples (Fig. S1 in the Supplement). The samples for microbial community investigation were stored with dry ice in transit and then frozen at $-80^{\circ} \mathrm{C}$ in the laboratory until further analysis.

In cloud water, the $\mathrm{pH}$ and conductivity were detected with a multi $\mathrm{pH} /$ conductivity/temperature handheld meter (pH/COND/TEMP, 6350) immediately after sampling. The liquid water content (LWC) of cloud droplets was measured with a fog monitor FM-120 (Droplet Measurement Technologies Inc., USA). The organic carbon (OC) in cloud water was detected using an an organic carbon-elemental carbon analyzer (Sunset Laboratory, Tigard, OR, USA). The major inorganic ions $\left(\mathrm{Cl}^{-}, \mathrm{NO}_{3}^{-}, \mathrm{SO}_{4}^{2-}, \mathrm{Na}^{+}, \mathrm{K}^{+}\right.$, $\mathrm{Ca}^{2+}, \mathrm{Mg}^{2+}$, and $\mathrm{NH}_{4}^{+}$) were quantified using the ionchromatography system (Dionex ICS-90). Hourly data, e.g., meteorological parameters, and $\mathrm{PM}_{2.5}$ were measured to evaluate air quality during cloud episodes (Table 1). The meteorological parameters including air temperature, relative humidity, wind direction, and wind speed were measured with an automatic meteorological station (PC-4, JZYG, China) in situ. The $\mathrm{PM}_{2.5}$ mass concentration was measured using a Model 5030 SHARP monitor (SHARP 5030, Thermo Fisher Scientific, Massachusetts, USA).

For each cloud episode, a $24 \mathrm{~h}$ back trajectory analysis was performed to determine the air mass from the most likely source region using the Hybrid Single-Particle Lagrangian Integrate Trajectories (HYSPLIT) model (http:// ready.arl.noaa.gov/HYSPLIT.php). Moreover, the wind rose diagram for the cloud process was drawn to clarify the prevailing wind direction and wind speed (origin, version 9.0, Origin Lab Corporation, Northampton, MA).

\subsection{DNA extraction and PCR amplification}

Genomic DNA was extracted in triplicate with the FastDNA spin kit for soil (MP Biomedicals, Solon, OH, USA) according to the manufacturer's directions. The concentration of DNA was determined spectrophotometrically (Nano-Drop 2000, Thermo, Wilmington, Delaware, USA). To check sample contamination, DNA was extracted through an identical extraction procedure for the blank samples. These blanks were PCR amplified together with the DNA samples extracted from cloud water samples. For the blank, no obvious bands and target fragments were detected by the examination of electrophoretic gel images.

The designed primer sets with the V3-V4 region of $16 \mathrm{~S}$ rRNA gene (338F-806R; Masoud et al., 2011), adapter and bar codes were selected in the Illumina Miseq sequencing. For each sample, a $25 \mu \mathrm{L}$ PCR mixture was prepared containing $10 \mu \mathrm{L}$ of $5 \times$ buffer, $1 \mu \mathrm{L}$ of dNTP $(10 \mathrm{mM}), 1 \mathrm{U}$ Phusion high-fidelity DNA polymerase, and $20 \mathrm{ng}$ of template DNA, $1 \mu \mathrm{L}$ of each $10 \mu \mathrm{M}$ modified primer, with double-distilled water until $25 \mu \mathrm{L}$. PCR was performed at $94^{\circ} \mathrm{C}$ for $2 \mathrm{~min} ; 25$ cycles of $94^{\circ} \mathrm{C}$ for $30 \mathrm{~s}, 56^{\circ} \mathrm{C}$ for $30 \mathrm{~s}$, and $72^{\circ} \mathrm{C}$ for $30 \mathrm{~s}$; $72^{\circ} \mathrm{C}$ for $5 \mathrm{~min}$; and held at $10^{\circ} \mathrm{C}$.

The PCR products were separated by $2 \%$ agarose gel electrophoresis and purified with the nucleic acid purification kit (AxyPrepDNA, Axygen, USA). Purified PCR products were quantified using a Qubit 3.0 fluorometer (Invitrogen, Carlsbad, CA) and then mixed to equal concentration. For each sample, $4 \mu \mathrm{L}$ of $10 \mathrm{nM}$ pooled DNA was denatured with $1 \mu \mathrm{L}$ of $0.2 \mathrm{~N} \mathrm{NaOH}$ at room temperature. Finally, Illumina paired-end sequencing was performed on a MiSeq platform (Illumina, Inc., San Diego, CA). After sequencing, two FASTQ files (read 1 and read 2) for each sample were generated on the MiSeq reporter software automatically. Raw 16S rRNA gene sequences are available at the Sequence Read Archive (SRA) under accession number SRX1904235. 
Table 1. Description cloud episodes at Mt Tai, China.

\begin{tabular}{|c|c|c|c|c|c|c|c|c|c|}
\hline Data & Samples & $\begin{array}{r}\text { Start time } \\
(\mathrm{BJT})\end{array}$ & $\begin{array}{r}\text { Stop time } \\
(\mathrm{BJT})\end{array}$ & $\begin{array}{r}\text { Duration } \\
\text { (h) }\end{array}$ & $\begin{array}{r}\mathrm{PM}_{2.5} \\
\left(\mu \mathrm{g} \mathrm{m}^{-3}\right)\end{array}$ & $\begin{array}{r}\mathrm{LWC} \\
\left(\mathrm{g} \mathrm{m}^{-3}\right)\end{array}$ & $\mathrm{pH}$ & $\begin{array}{r}\mathrm{EC} \\
\left(\mu \mathrm{S} \mathrm{cm}^{-1}\right)\end{array}$ & $\begin{array}{r}\mathrm{OC} \\
\left(\mathrm{mg} \mathrm{L}^{-1}\right)\end{array}$ \\
\hline \multirow[t]{3}{*}{24 Jul 2014} & CE1-1 & $08: 50$ & $15: 30$ & $6: 40$ & 105.07 & 0.21 & 4.03 & 583 & ND \\
\hline & CE1-2 & $15: 30$ & $17: 30$ & $2: 00$ & 22.35 & 0.23 & 4.32 & 219.2 & ND \\
\hline & CE1-3 & $17: 30$ & $22: 51$ & $5: 21$ & 14.66 & 0.24 & 5.74 & 104.4 & ND \\
\hline 5 Aug 2014 & CE2-1 & $06: 45$ & $09: 17$ & $2: 32$ & 30.36 & 0.22 & 5.80 & 275.7 & ND \\
\hline 5-6 Aug 2014 & CE3-1 & 19:05 & 04:01 & $8: 56$ & 42.25 & 0.10 & 5.10 & 501 & ND \\
\hline \multirow[t]{3}{*}{ 14-15 Aug 2014} & CE4-1 & $22: 41$ & $00: 44$ & $2: 03$ & 42.69 & 0.02 & 6.36 & 170.4 & $\mathrm{BDL}$ \\
\hline & CE4-2 & $00: 44$ & 05:06 & $4: 22$ & 47.98 & 0.03 & 5.34 & 86.34 & 0.04 \\
\hline & CE4-3 & 05:06 & 06:03 & $0: 57$ & 36.88 & 0.02 & 4.89 & 64.95 & BDL \\
\hline 17 Aug 2014 & CE5-1 & $10: 10$ & $11: 18$ & $1: 08$ & 63.18 & 0.39 & 5.20 & 120.5 & 0.11 \\
\hline 17-18 Aug 2014 & CE6-1 & $22: 18$ & $01: 25$ & $3: 07$ & 54.33 & 0.10 & 3.80 & 321.8 & 0.02 \\
\hline \multirow[t]{3}{*}{23 Aug 2014} & CE7-1 & $02: 30$ & $04: 38$ & 2:08 & 30.45 & 0.20 & 4.38 & 356.2 & 0.03 \\
\hline & CE7-2 & $04: 38$ & $06: 21$ & $1: 43$ & 23.39 & 0.22 & 5.01 & 207.5 & 0.15 \\
\hline & CE7-3 & $06: 21$ & 09:20 & $2: 59$ & 41.60 & 0.21 & 5.74 & 187.6 & 0.21 \\
\hline
\end{tabular}

* Abbreviations: CE, cloud episode; BJT, Beijing Time, which equals UTC +8 ; LWC, the cloud liquid water content; EC, electric conductivity; OC, organic carbon in cloud water; ND, not detected due to instrument failure; BDL, below detection limitation.

\subsection{Illumina high-throughput sequencing and analyzing}

Raw sequences were processed using the QIIME packages (Kuczynski et al., 2011). The pair-end reads were firstly merged with an overlap length greater than $10 \mathrm{bp}$. Then, the adapter, bar codes, and primers were removed from the merged sequences. Subsequently, the trimmed sequences with a length shorter than $200 \mathrm{bp}$, a quality score lower than 25, and homologous bases longer than $8 \mathrm{bp}$, containing ambiguous characters, were screened. Finally, chimeric sequences were distinguished using the Usearch61 algorithm and removed from the dataset. Optimized sequences were clustered into operational taxonomic units (OTUs) at the threshold of $97 \%$ similarity with the usearch61 algorithm. Single OTUs were removed and taxonomy was assigned to each representative OTU using the Ribosomal Database Project (RDP) classifier in QIIME, with a minimum confidence cutoff of $80 \%$ against the silva reference database (silva 119, http://www.arb-silva.de/) to the genus level. Subsequently, we focused on the bacterial genera including species known or suspected to be opportunistic pathogen and performed a systematic literature review to identify potential pathogenic bacteria in water habitats (Bibby et al., 2010; Guo and Zhang, 2012; Luo and Angelidaki, 2014).

To acquire bacterial community function, Phylogenetic Investigation of Communities by Reconstruction of Unobserved States (PICRUSt) was performed. The PICRUSt can be used to predict the metabolic function pathway from corresponding bacteria and archaea and provide a community's functional capabilities based on the 16S rRNA gene sequence (Langille et al., 2013; Corrigan et al., 2015; Wu et al., 2016). In the present study, the phylogenetic and functional capacities for the bacteria in cloud water are of great interest to help understand their roles in the atmosphere, ecosystem, and health. Bacterial community functional profiles were predicted from 16S rRNA gene using the PICRUSt program and annotated against with the Kyoto Encyclopedia of Gene and Genomes (KEGG) database. Spearman's correlation coefficients were calculated to link the pairwise comparison of KEGG pathway and genus. Selected KEGG pathways related to metabolism and disease infection, and predominant genera are included in the heat map. Correlation is significant at a $p$ value less than 0.05 and 0.01 .

Alpha diversity was assessed by examining the rarefaction curves, Shannon-Wiener curves, and rank-abundance curves calculated with Mothur (v.1.34.0; http://www.mothur. org; Schloss et al., 2009); these were visualized in R project (v.3.1.3; https://www.r-project.org/). Community richness estimators including the observed OTUs, nonparametric Chao1, Abundance-based Coverage Estimator (ACE), and community diversity estimators including Shannon and Simpson indexes were also calculated with Mothur. Moreover, Good's coverage was used to evaluate the sequencing depth.

Hierarchical cluster (Hcluster) and principal coordinate analysis (PCoA) were performed to visualize the changes in bacterial community for the collected samples. Hcluster and PCoA plots were constructed depending on the Bray-Curtis similarity index calculated with the abundance of OTUs using the biodiversity package in R (Kindt and Coe, 2005). The difference in OTU composition for samples collected in polluted and non-polluted cloud episodes was tested by the analysis of similarity (ANOSIM; Clarke, 1993). ANOSIM was implemented with the VEGAN package in R. Linear discriminant analysis effect size (LEfSe; http://huttenhower.sph. harvard.edu/galaxy/) was applied to identify differentially abundant bacterial taxa associated with polluted and non- 
polluted cloud episodes at genus or higher taxonomy levels (Segata et al., 2011). For all statistical tests, the $p$ value less than 0.05 and 0.01 was considered significant.

\subsection{Interaction between bacterial community structure and environmental variables}

Correlation between bacterial community and environmental variables was first performed using a detrended correspondence analysis (DCA) to estimate the gradient length. The resulting length (0.99) indicates that a linear model was appropriate; hence, RDA was subsequently performed. RDA was elaborated with the predominant bacterial matrix and environmental data matrix including $\mathrm{PM}_{2.5}$ mass concentration, meteorological conditions, water $\mathrm{pH}$, electric conductivity, and major ions in cloud water (Anderson and Willis, 2008). Interset correlations were used to determine the most important environmental variables in determining community structure. To explain the species data, cumulative fit per species as fraction of variance of species was analyzed. The crucial environmental factors for the ordination space, and the species closely correlated with environmental factors were selected. Analysis was performed in Canonical Community Ordination for Windows (Canoco, v 4.5).

\section{Results and discussions}

\subsection{Definition of polluted and non-polluted cloud episodes}

In the present study, we first defined cloud water samples according to the air pollution conditions. The collected cloud water was considered to be a polluted sample under air pollution. However, in Hcluster and PCoA analysis (Fig. S3), sample CE1-2 (the non-polluted sample) was separated from other non-polluted samples but closed to the polluted samples. The reclassification of cloud water samples was combined with the major ions in water droplets. By checking the major ions, we observed that although the $\mathrm{PM}_{2.5}$ concentration for sample CE1-2 was low, a relatively high major-ion concentration was detected (Fig. S1). Therefore, we categorized sample CE1-2 as polluted sample. The cluster and PCoA analysis also confirmed the reclassification (Fig. S4).

Although the predominant bacteria are similar between polluted and non-polluted cloud episodes, significant disparity is also identified. ANOSIM analysis suggest that OTUs from polluted samples were grouped into one large cluster and separated from the non-polluted clusters (ANOSIM comparison, $R=0.683, p<0.05$ ). Cluster analysis including PCoA and Hcluster indicated a highly similar community composition in polluted samples, regardless of the cloud episodes (Fig. S3). Principal component analysis based on the relative abundance of genera showed similar clustering patterns (Fig. S4), and the polluted samples also shared high similarity in the bacterial community structure.

\subsection{Microbial community in cloud water}

Information on the bacterial community in fog/cloud droplets is scarce; our study provided a comprehensive investigation of the bacterial community. From the 13 samples collected during seven cloud episodes, a total of 232148 highquality sequences were obtained after quality filtering, and OTUs ranged from 975 to 1258 (Table 2). This was similar to other sequence-based surveys such as the atmospheric bacteria in a dust storm (1214l; Katra et al., 2014) and bacteria in rainwater in July (1542; Cho and Jang, 2014). The identification of OTUs at different taxonomic levels yielded 359 species, 411 genera, 152 families, 70 orders, 38 classes, and 26 phyla. Across all samples, Proteobacteria were the dominant phylum, followed by Bacteroidetes, Cyanobacteria, Firmicutes, Deinococcus-Thermus, Actinobacteria, and Nitrospirae (Fig. 1). These taxa are predominant bacteria in clouds determined by Sanger sequencing and tagged pyrosequencing (Bowers et al., 2009), and they are also the typical culturable heterotrophic bacteria from clouds broadly distributed in aquatic and terrestrial habitats (Amato et al., 2005; Kourtev et al., 2011). In the present study, Fig. S5 shows the dominant genera collected during cloud process. The predominant genera from Proteobacteria (including Acinetobacter, Stenotrophomonas, Pseudomonas, Sphingomonas, Massilia, Delftia, Brevundimonas), Firmicutes (Bacillus), and Bacteroidetes (Empedobacter) were similar across all samples. The identified genera were also similar to other studies of microorganisms in fog/cloud water. Fuzzi et al. (1997) investigated bacteria in fog droplets in a highly polluted area and found that the predominant genera were Pseudomonas, Bacillus, and Acinetobacter. Amato et al. (2007b) observed more diverse genera from the phylum of Proteobacteria, Bacteroidetes, Actinobacteria, and Firmicutes, mainly belonging to Pseudomonas, Sphingomonas, Staphylococcus, Streptomyces, and Arthrobacter. Ahern et al. (2007) investigated the bacterial community in clouds collected in Scotland and found that the dominant species were Pseudomonas and Acinetobacter.

In the bacterial community, the aforementioned taxa contained a series of species participating in the atmospheric hydrological and biochemical cycle (Amato et al., 2007b; Delort et al., 2010). Community function analysis estimated with the PICRUSt algorithm confirmed this viewpoint. After PICRUSt analysis, pathways with participants of less than $10 \%$ were removed, leaving 225 nonhuman-gene KEGG pathways. These predominant pathways were mainly related to the amino acid metabolism, the carbohydrate metabolism, cell motility, cellular processes and signaling, energy metabolism, enzyme families, folding, sorting and degradation, membrane transport, the nucleotide metabolism, the nucleotide metabolism, replication and repair, signal transduction, transcription, and translation (Fig. S6). Besides the pathways associated with the microbial physiological metabolism, we focused on the pathways of the 
Table 2. Summary of bacterial diversity and richness of cloud water.

\begin{tabular}{|c|c|c|c|c|c|c|c|}
\hline Sample ID & Reads & OTUs & ACE & Chao1 & Coverage & Shannon & Simpson \\
\hline \multicolumn{8}{|l|}{ Polluted cloud episodes } \\
\hline CE1-1 & 18213 & 975 & 1835 & 1491 & 0.98 & 3.94 & 0.065 \\
\hline CE1-2 & 18702 & 1184 & 1841 & 1730 & 0.97 & 4.19 & 0.062 \\
\hline CE2-1 & 19914 & 1125 & 1756 & 1684 & 0.97 & 3.96 & 0.063 \\
\hline CE3-2 & 18199 & 1022 & 2082 & 1582 & 0.97 & 3.97 & 0.065 \\
\hline CE4-1 & 18350 & 941 & 1828 & 1461 & 0.98 & 3.60 & 0.095 \\
\hline CE4-2 & 17707 & 967 & 1522 & 1427 & 0.98 & 3.67 & 0.090 \\
\hline CE4-3 & 17397 & 981 & 2091 & 1611 & 0.97 & 3.81 & 0.083 \\
\hline CE5-1 & 16384 & 1132 & 1814 & 1790 & 0.97 & 4.32 & 0.055 \\
\hline CE6-1 & 16896 & 1186 & 1997 & 1872 & 0.97 & 4.13 & 0.067 \\
\hline CE7-1 & 16350 & 1103 & 2501 & 1795 & 0.97 & 3.90 & 0.081 \\
\hline CE7-3 & 18122 & 1258 & 1958 & 1999 & 0.97 & 4.38 & 0.053 \\
\hline \multicolumn{8}{|l|}{ Non-polluted cloud episodes } \\
\hline CE1-3 & 17662 & 1173 & 1689 & 1687 & 0.97 & 4.71 & 0.033 \\
\hline CE7-2 & 18252 & 1150 & 1732 & 1673 & 0.97 & 4.37 & 0.043 \\
\hline Aerosol (Katra et al., 2014) & 4020 & 1412 & & 2142 & 0.83 & & \\
\hline Bioaerosol (Madsen et al., 2015) & & & & & & $2.64-3.05$ & $0.82-0.92$ \\
\hline Rainwater in July (Cho and Jang, 2014) & 3055 & 1542 & 13083 & 6387 & & & \\
\hline $\mathrm{PM}_{2.5}$ in summer (Franzetti et al., 2011) & & 2222 & & 4036 & & & \\
\hline TSP annual (Bertolini et al., 2013) & 271587 & $765-26187$ & & 107 & & 2.40 & \\
\hline
\end{tabular}

The diversity indexes including OTUs, ACE, Chao1, coverage, Shannon, and Simpson were defined at $97 \%$ sequence similarity. Abbreviations: CE, cloud episodes; TSP, total suspended particulate matter.

(a)
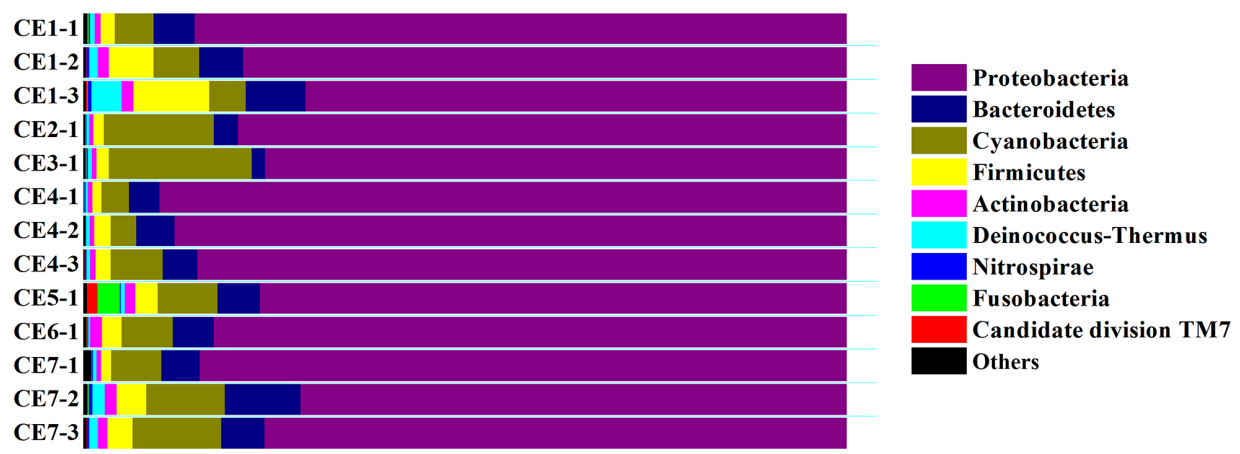

(b) CE1-1
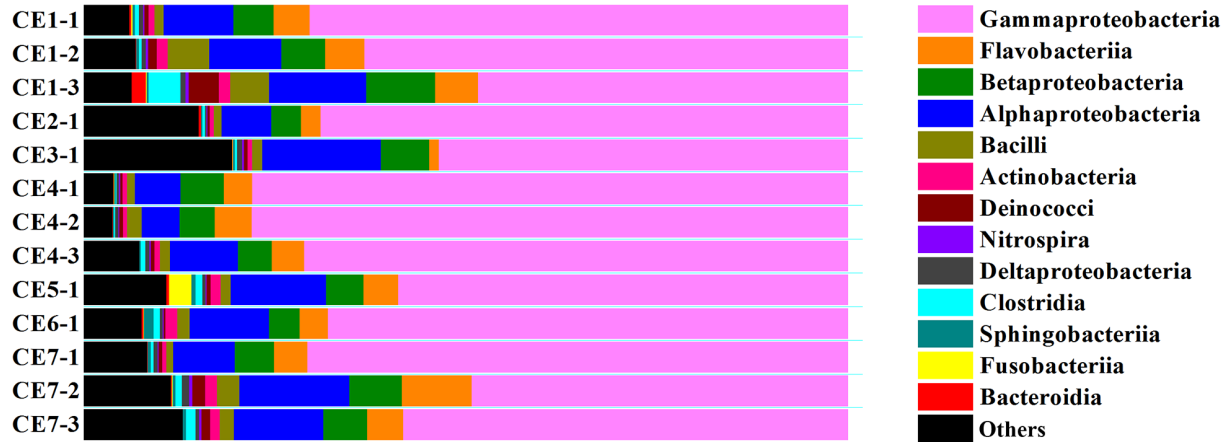

Figure 1. Bacterial community variation for cloud episodes at the phylum (a) and class (b) level. CE refers to the cloud episodes. Bar graphs for each sample represent the percentage of taxa assigned to each phylum with $80 \%$ bootstrap confidence. Taxonomic summary of the most abundant taxa (more than $1 \%$ ) across all cloud samples are indicated in the figure. 


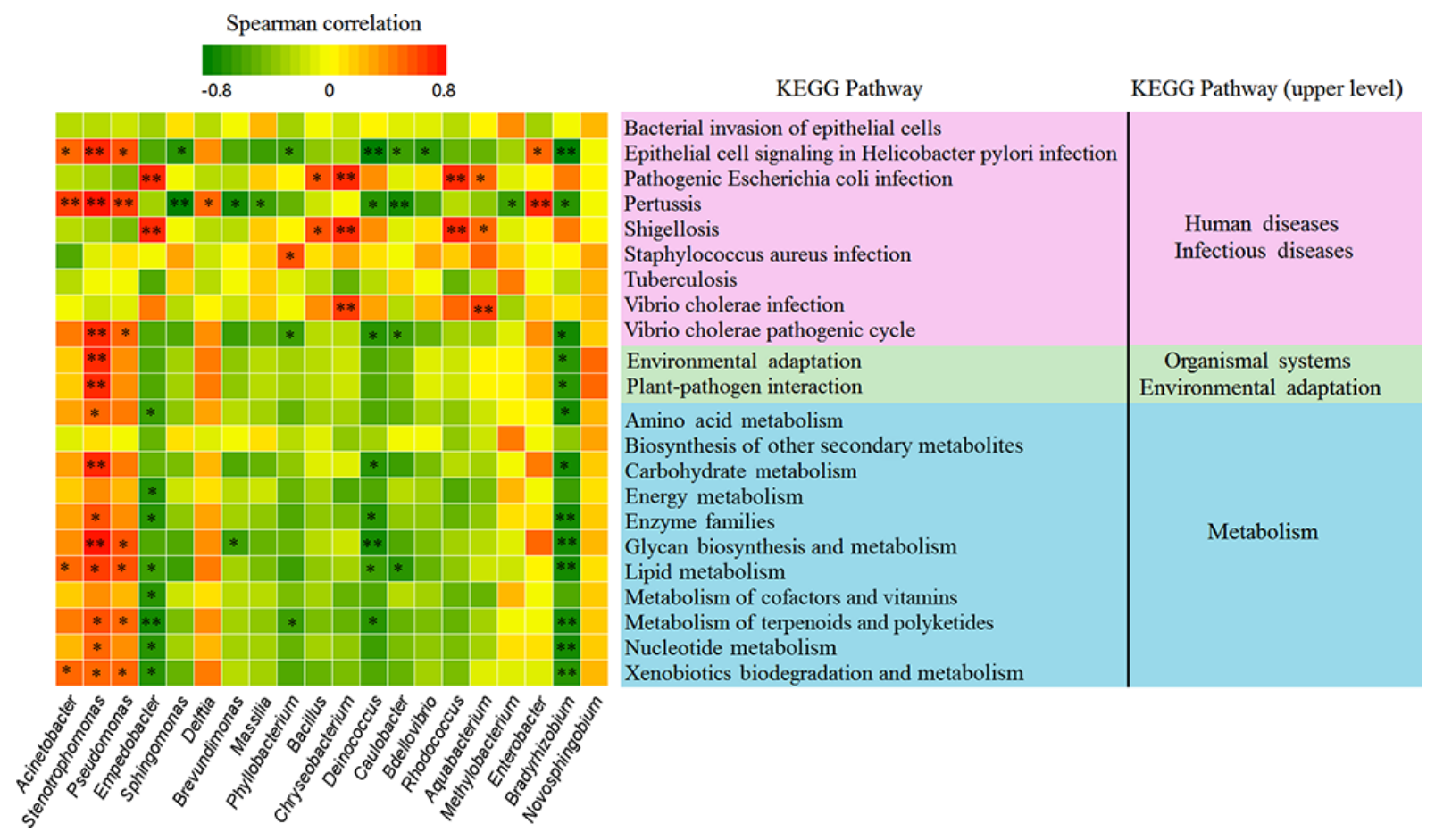

Figure 2. Bacterial taxa are related to KEGG pathways. Bacterial gene functions were predicted based on 16S rRNA gene sequences using the PICRUSt algorithm and annotated from KEGG databases. Spearman's correlation coefficients were calculated for each pairwise comparison of genus and KEGG pathway. Selected KEGG pathways related to metabolism and disease infection and predominant genera are included in the heat map. Red color refers to the positive correlation, and green indicates a negative correlation. Correlation is significant at $* p<0.05$, $* * p<0.01$.

microbial metabolism in a variety of natural environments. Fog/cloud droplets contain carbon and nitrogen compounds, which could be available substrate for microbial growth in the atmosphere. The predicted function of the metabolism was likely attributed to the bacterial gene from the identified taxa (Fig. 2). Previous studies have demonstrated that the atmospheric bacterial community contained a metabolically diverse group from a wide range of water/soil habitats. For example, Acinetobacter, the most abundant genus, widely distributed in land or ocean, was positively associated with biodegradation, leaching, and the removal of several organic and inorganic man-made hazardous wastes (Abdelelhaleem, 2003). Stenotrophomonas and Pseudomonas, positively correlated with carbohydrate metabolism and glycan biosynthesis and metabolism, are well-known for their striking capability to utilize numerous carbon sources. They have been widely utilized in the degradation and transformation of complex organic compounds in a wide range of habitats (Boonchan et al., 1998; Stanier et al., 2010). Moreover, predicted functions associated with human disease are of particular interest. For instance, some species from Acinetobacter, were positively associated with infection disease (Nemec et al., 2001). Empedobacter from Bacteroidetes are widely distributed in water habitats and are of human clinical origins; certain species from Empedobacter are ranked as potential pathogens (Hugo et al., 2005).

In cloud water, a series of genera adapted to harsh environments were also identified. The ability to survive in low concentrations of nutrients has been reported for Sphingomonas, which can metabolize a variety of carbon compounds, even toxic compounds (Xu et al., 2006). Similar to Sphingomonas, members of Brevundimonas are well known to withstand an extreme, harsh environment (Kopcakova et al., 2014). The spore-forming bacterium Bacillus from Firmicutes is commonly found in bioaerosol, cloud water, and rainwater and could survive in a cold environment (Després et al., 2012). Similar to Bacillus, some strains of Pseudomonas found in Antarctic environments revealed cold adaption (Bozal et al., 2003). Certain Pseudomonas species in cloud water were psychrophiles; they grow faster at $5{ }^{\circ} \mathrm{C}$ than at a high temperature (17 or $27^{\circ} \mathrm{C}$; Amato et al., 2007b). Members of Deinococcus from Deinococcus-Thermus are able to withstand extreme radiation conditions that could potentially ensure adaption to the cloud environment (Mattimore and Battista, 1996).

Although most bacterial ecophysiological roles in biogeochemical cycles are generally established based on soils and water habitats, information about bacterial activity in cloud water is available. The identification of microorganisms in 
Table 3. The identified bacterial species in cloud water samples correlated with the potential ecological function.

\begin{tabular}{|c|c|c|c|c|}
\hline Genus & Identified species & Habitats & Ecological role & Reference \\
\hline Acinetobacter ${ }^{\mathrm{GP}}$ & A. schindleri & soil/water & CNN or IN; opportunistic pathogens & $\begin{array}{l}\text { Mortazavi et al. (2008); } \\
\text { Nemec et al. (2001) }\end{array}$ \\
\hline Bacillus $^{\mathrm{FR}}$ & B. anthracis & soil/water/air & CNN or IN; opportunistic pathogens & $\begin{array}{l}\text { Makino and Cheun (2003); } \\
\text { Mortazavi et al. (2008) }\end{array}$ \\
\hline \multirow[t]{2}{*}{ Brevundimonas $^{\mathrm{BP}}$} & B. diminuta & soil/water & $\mathrm{CNN}$ & $\begin{array}{l}\text { Bauer et al. (2003); } \\
\text { Han and Andrade (2005) }\end{array}$ \\
\hline & B. vesicularis & soil/water & opportunistic pathogens & Gilad et al. (2009) \\
\hline Caulobacter $^{\mathrm{AP}}$ & Caulobacter. sp. & water & metabolism/biodegradation & Nakamura et al. (2007) \\
\hline Chryseobacterium $^{\mathrm{BA}}$ & $\begin{array}{l}\text { C. aquaticum } \\
\text { C. jejuense }\end{array}$ & $\begin{array}{l}\text { soil/water } \\
\text { soil/water }\end{array}$ & protect and promote plants growth & $\begin{array}{l}\text { Gandhi et al. (2009) } \\
\text { Ben Abdeljalil and Vallance (2016) }\end{array}$ \\
\hline Clostridium $^{\mathrm{FR}}$ & C. tertium & soil/gut & opportunistic pathogens & Miller et al. (2001) \\
\hline Comamonas $^{\mathrm{BP}}$ & C. testosteroni & soil/water & metabolism/biodegradation & Goyal and Zylstra (1996) \\
\hline Cyanobacterium $^{\mathrm{CY}}$ & Cyanobacterium sp. & soil/water & carbon and nitrogen fixing & Jha et al. (2004) \\
\hline Deinococcus ${ }^{\mathrm{DT}}$ & D. aquatilis & soil/water & extremophiles, radiation-resistant & Kämpfer et al. (2009) \\
\hline Delftia $^{\mathrm{BP}}$ & D. tsuruhatensis & soil/water & metabolism/biodegradation & Geng et al. (2009) \\
\hline Empedobacter $^{\mathrm{BA}}$ & E. brevis & soil/water/plant & opportunistic pathogens & Bottone et al. (1992) \\
\hline Methylobacterium ${ }^{\mathrm{AP}}$ & $\begin{array}{l}\text { M. aquaticum } \\
\text { M. adhaesivum }\end{array}$ & $\begin{array}{l}\text { water } \\
\text { soil//water }\end{array}$ & methylotrophic, carbon fixing & $\begin{array}{l}\text { Gallego et al. (2005) } \\
\text { Gallego et al. (2006) }\end{array}$ \\
\hline Moraxella $^{\mathrm{GP}}$ & M. osloensis & soil/animal & opportunistic pathogens & Banks et al. (2007) \\
\hline Novosphingobium $\mathrm{AP}$ & N. aromaticivorans & soil/water & metabolism/biodegradation & Bell and Wong (2007) \\
\hline Staphylococcus ${ }^{\mathrm{GP}}$ & S. equorum & soil/water/clinic & opportunistic pathogens & Nováková et al. (2006) \\
\hline Phyllobacterium $^{\mathrm{AP}}$ & P. myrsinacearum & soil/plant & rhizosphere bacteria, nitrogen fixation & Gonzalezbashan et al. (2000) \\
\hline Pseudomonas $\mathrm{GP}$ & $\begin{array}{l}\text { P. psychrotolerans } \\
\text { P. geniculate }\end{array}$ & $\begin{array}{l}\text { soil/water } \\
\text { soil/water/plant }\end{array}$ & $\begin{array}{l}\text { extremophiles, psychrotolerant } \\
\text { metabolism/biodegradation }\end{array}$ & $\begin{array}{l}\text { Hauser et al. (2004) } \\
\text { Gopalakrishnan et al. (2015); } \\
\text { Liu et al. (2014) }\end{array}$ \\
\hline & & & $\mathrm{CNN}$ or IN & $\begin{array}{l}\text { Amato et al. (2015); } \\
\text { Joly et al. (2013) }\end{array}$ \\
\hline Rhodococcus $^{\mathrm{AC}}$ & R. ruber & soil/water & metabolism/biodegradation & Bock et al. (1996) \\
\hline Sphingomonas ${ }^{\mathrm{AP}}$ & $\begin{array}{l}\text { S. faeni } \\
\text { S. kaistensis } \\
\text { S. leidyi }\end{array}$ & $\begin{array}{l}\text { soil/water } \\
\text { soil/water } \\
\text { soil/water }\end{array}$ & $\begin{array}{l}\text { CNN or IN; psychrotolerant } \\
\text { metabolism/biodegradation }\end{array}$ & $\begin{array}{l}\text { Ponder et al. (2005) } \\
\text { Busse et al. (2003) } \\
\text { Glaeser and Kämpfer (2014) }\end{array}$ \\
\hline Stenotrophomonas $\mathrm{GP}$ & S. rhizophila & soil/water/plant & $\mathrm{CNN}$ or IN; rhizosphere bacteria & $\begin{array}{l}\text { Mortazavi et al. (2008); } \\
\text { Wolf et al. (2002) }\end{array}$ \\
\hline
\end{tabular}

the barren-nutrition, low-temperature, and radiation environment encountered in clouds is expected since similar bacterial species have been retrieved and proved to be active in harsh environments. Their adaption to the specific environments in fog/cloud water with a potential role in the nucleation and metabolism of organic pollutants demonstrated their potential importance in the atmospheric biochemistry cycle.

\subsection{Implications for human health and the ecosystem}

Bacteria in fog/cloud water have been known for decades, but detailed information on community composition and potential ecophysiological role is severely limited. Bioaerosols in fog/cloud are complex assemblages of airborne and exogenic microorganisms, likely due to emission and resuspension from various terrestrial environments, e.g., soil, water, plants, animals, or human beings. In the atmosphere, fog/clouds may be a favorable niche for bacteria and these bacteria could thrive and influence cloud processes by acting as cloud condensation nuclei and ice nuclei. Bacteria including pathogenic or beneficial species can also be attached to particles or incorporated into water droplets of fog/clouds. During fog/cloud or rain processes, they can be deposited back on land via deposition and possibly cause human infections and affect the diversity and function of aquatic/terrestrial ecosystems (Kaushik and Balasubramanian, 2012; Simmons et al., 2001; Vaïtilingom et al., 2012; Fig. 3 and Table 3).

Atmospheric bacteria are efficient cloud condensation nuclei, and water vapor can be condensed on bacterial cell surface (Andreae and Rosenfeld, 2008). The hygroscopic growth of bacteria below water saturation and supersaturations has been observed for some species; e.g., Bauer et al. (2003) found that Brevundimonas diminuta was activated at $<0.1 \%$ supersaturation. Strains from Pseudomonas, Rhodococcus, and Bacillus found in cloud water samples 


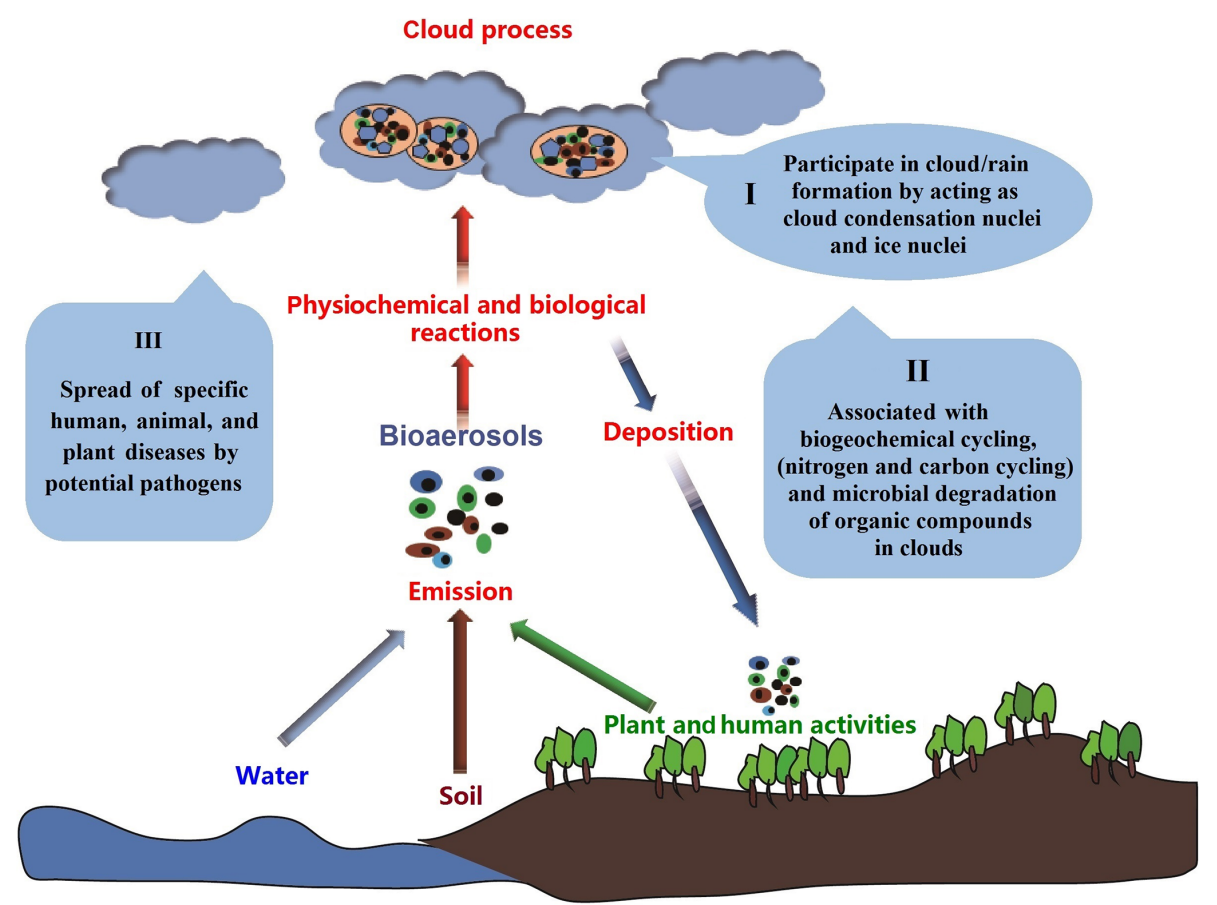

Figure 3. Schematic representation of bioaerosols' life cycle and potential influence on atmosphere, ecosystem, and human health, modified from Pöschl (2006). In clouds, the bacterial potential functions are indicated in the figure. Bioaerosols are emitted from various terrestrial environments, e.g., soil, water, plants, animals, or human beings, which may include pathogenic or functional species. These bacteria can be attached to particles or incorporated into water droplets of clouds/fog. Certain species can serve as biogenic nuclei for cloud condensation nuclei (CCN) and ice nuclei (IN), which induce rain formation, precipitation, and wet deposition of gases and particles. For the potential pathogens and functional bacteria, during cloud processes, they can be deposited back to land via deposition and possibly induce human infections and affect the diversity and function of aquatic and terrestrial ecosystems.

could produce biosurfactants and act as cloud condensation nuclei (Delort et al., 2010). They may form cloud droplets combined with aerosol particles at lower supersaturations and quickly grow to large-sized droplets and facilitate rain formation (Möhler et al., 2007). Moreover, Pseudomonas could induce ice nucleation at a warmer temperature than usual (Amato et al., 2015). Simulation experiments on cloud formation suggest that Pseudomonas first acted as a CCN and then induced the freezing and ice nucleation process (Andreae and Rosenfeld, 2008). In addition to Pseudomonas, other bacteria from Acinetobacter, Bacillus, Flavobacterium, Sphingomonas, and Stenotrophomonas sp. (Table 3), were ice nucleation active (Mortazavi et al., 2008). Gaining an understanding of their possible role in cloud condensation and ice nucleation processes might provide a new view of bacterial communities' influence on meteorology and climate change.

In addition, microorganisms living in fog/cloud may play a vital role in atmospheric biochemistry. The detection of bacteria in cloud water associated with the biotransformation of organic compounds raises questions regarding a general understanding of their potential role in atmospheric chemistry. The identified species from Pseudomonas, Rhodococcus, Sphingomonas, Delftia, and Comamonas (Table 3) mainly participated in the biodegradation of organic compounds. Extensive studies have illustrated their capability of metaboling hydrocarbon compounds, even toxic pollutants, e.g., aromatic compounds (Bock et al., 1996; Busse et al., 2003; Geng et al., 2009; Goyal and Zylstra, 1996). Two strains from Stenotrophomonas (S. rhizophila) and Phyllobacterium (P. myrsinacearum) are typical rhizospheric microorganisms, which were typically dispersed into the atmosphere from soil. As plant-associated strains, S. rhizophila fulfill plantprotective roles and have been safely applied in biotechnology (Alavi et al., 2013). P. myrsinacearum is a predominant rhizospheric bacterium, which has been utilized in plant growth promotion and biological control of soil-borne diseases due to its capability of azotification (Gonzalezbashan et al., 2000). The methylotrophic Methylobacterium (M. aquaticum and M. adhaesivum) typically inhabit in soil and water. Previous studies have demonstrated its carbon-fixing function in the ecosystem (Gallego et al., 2006; Gallego et al., 2005). Similar to Methylobacterium, Cyanobacterium sp., widely distributed in soil, water, and various arid environments, has excellent nitrogen- and carbon-fixing ability (Jha et al., 2004). Cloud water seems to harbor highly diverse bacterial communities in ecosystem, which may be due to the atmospheric mixing of diverse point source origins in the rhi- 

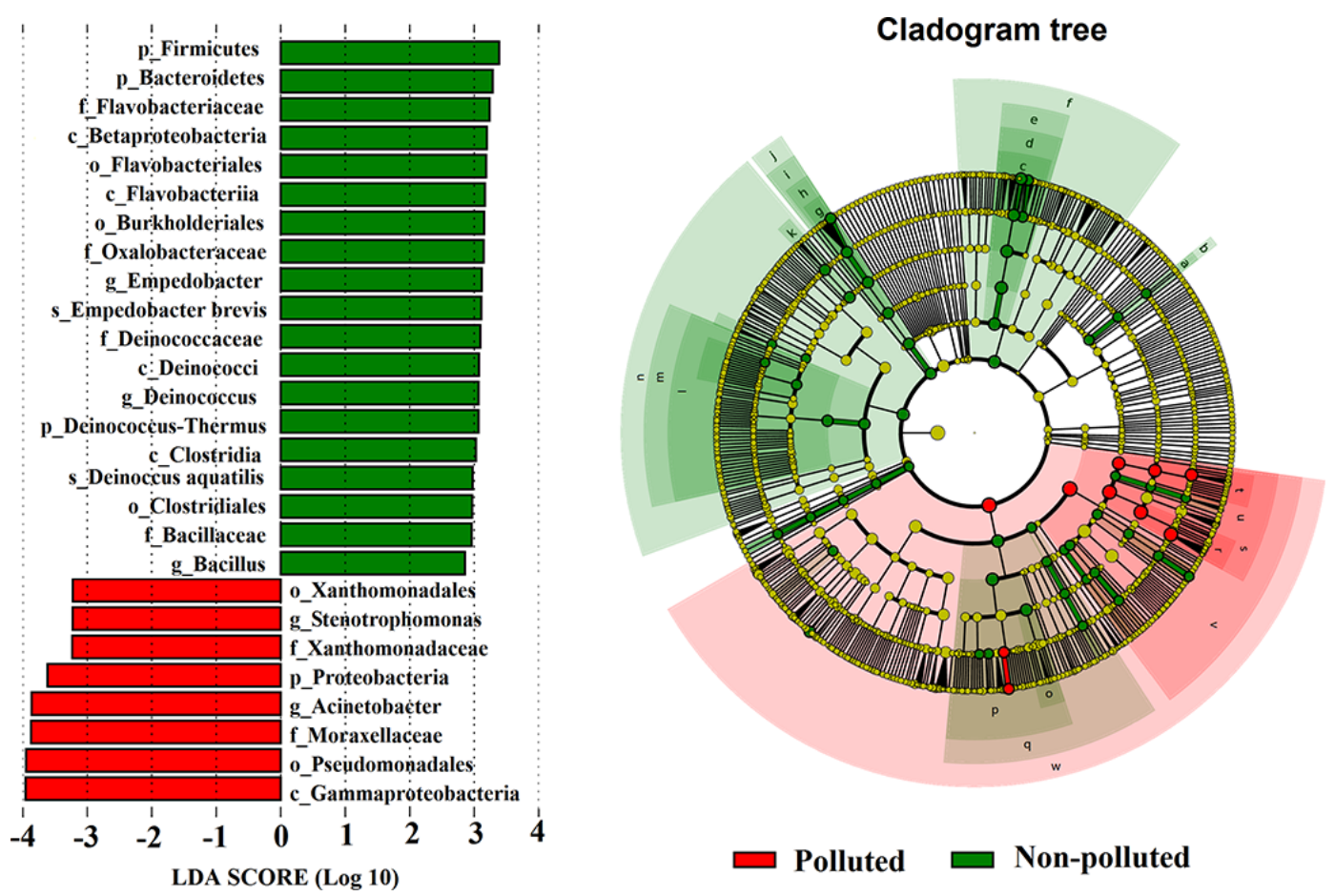

Figure 4. Distinct bacterial taxa between polluted and non-polluted cloud episodes identified by linear discriminant analysis (LDA) coupled with effect size (LEfSe). The LDA effect sizes (left) were calculated using the default parameters. The taxonomic cladogram (right) was visualized with LDA values higher than 3.5 comparing all bacterial taxa. The significantly distinct taxon nodes are colored in red (polluted samples) and green circles (non-polluted samples). The nonsignificant bacterial taxa are indicated with yellow circles. The abbreviation in the cladogram tree: a: g_Rhodococcus, b: f_Nocardiaceae, c: f_Flavobacteriaceae, d: o_Flavobacteriales, e: c_Flavobacteriia,f: p_Bacteroidetes, g: f_Deinococcaceae, h: o_Deinococcales, i: c_Deinococci, j: p_Deinococcus-Thermus, k: f_Bacillaceae, l: o_Clostridiales, m: c_Clostridia, n: p_Firmicutes, o: f_Oxalobacteraceae, p: o_Burkholderiales, q: c_ Betaproteobacteria, r: f_Moraxellaceae, s: o_Pseudomonadales, t: f_Xanthomonadaceae, u: o_Xanthomonadales, v: c_Gammaproteobacteria, w: p_Proteobacteria. Abbreviations: p - phylum; c - class; o - order; f - family; g - genus; $\mathrm{s}$ - species.

zosphere, soil, and water, and this may possibly participate in the biodegradation of organic compounds in cloud water.

In addition, bacterial genera containing potential pathogens were of particular interest after sequencing. By alignment with the reference pathogen database, sequences highly similar to potential pathogens were identified. In the present study, the presence of potential pathogen sequences indicated occasional distribution and dispersion of pathogens in cloud water (Table 3). The identified opportunistic pathogens from Empedobacter, e.g., E. brevis, can easily be isolated from clinical resources, which may be associated with eye infections (Bottone et al., 1992). Occurrences of Staphylococcus equorum in cloud water can be expected since Staphylococcus are frequently isolated from airborne samples (Seo et al., 2008). They can reside on the skin and mucous membranes of humans and induce severe infections (Nováková et al., 2006). Similarly, species from Brevundimonas (B. vesicularis and B. diminuta) can induce virulent infections, often associated with the nervous system or bacteraemia (Gilad et al., 2009; Han and Andrade, 2005). Moreover, the pathogenic strains from Acinetobacter
(A. schindleri) and Moraxella (M. osloensis) are associated with skin and wound infections, bacteremia, and pneumonia (Banks et al., 2007; Nemec et al., 2001).

Previous studies on potential pathogens are mostly focused on atmospheric particulate matter $\left(\mathrm{PM}_{2.5}\right.$ and $\mathrm{PM}_{10}$; Cao et al., 2014; Creamean et al., 2013) and rainwater (Kaushik and Balasubramanian, 2012; Simmons et al., 2001) and have indicated that health-risk-related bacteria in atmospheric samples are of particular interest. For cloud/fog water, studies of health risks to individuals are typically focused on the chemical characteristic, e.g., the low pH (acid fog; Hackney et al., 1989) and PAH (Ehrenhauser et al., 2012). The limited literature that has discussed the microorganisms in fog/cloud water suggested potential pathogens in fog/cloud water (Vaïtilingom et al., 2012). Vaïtilingom et al. (2012) find potential plant pathogens such as Pseudomonas syringae and Xanthomonas campestris and suggest that these living plant pathogens could then infect new hosts through precipitation. Possibly, a greater survival of human pathogens may be supported in the atmosphere. Fog/cloud and rain process are part of the atmospheric life cycle and 


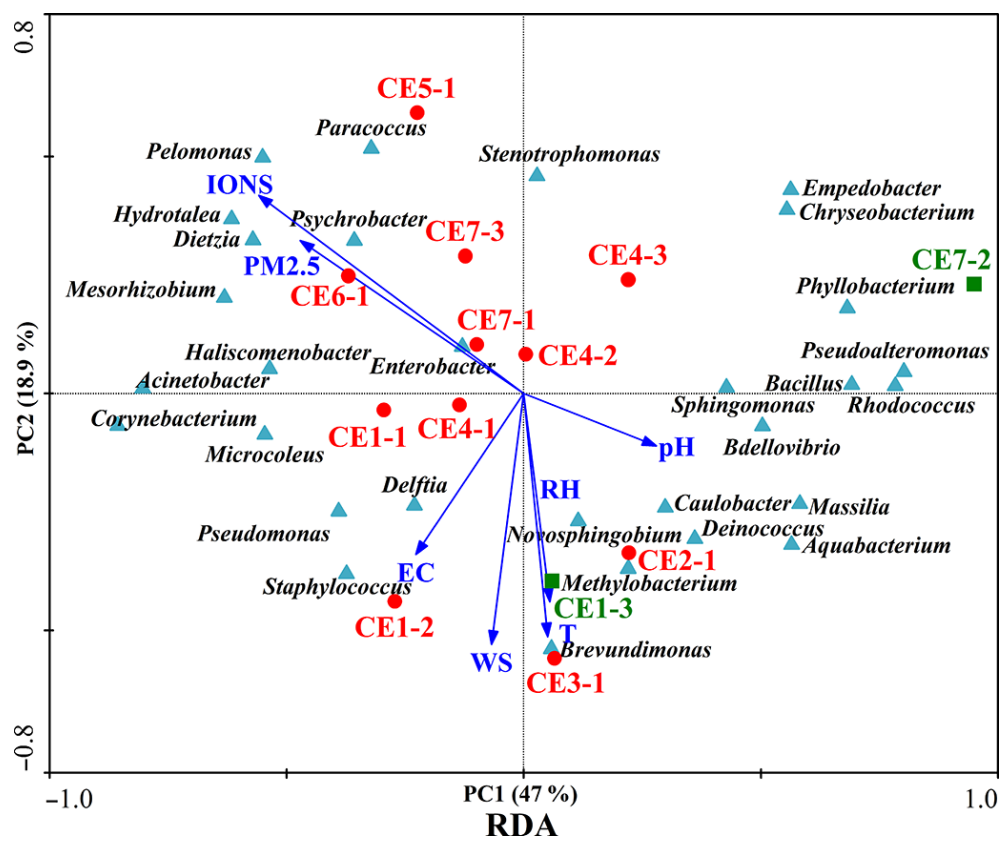

Figure 5. Biplot of the environmental variables and genus-level community structure using a redundancy analysis model (RDA), describing the variation in bacterial community explained by environmental variable. CE refers to cloud episodes. Polluted episodes are indicated by red circles, and non-polluted episodes are green squares. Species data are listed in Table S2. The selected environmental variables are significant $(p<0.05)$ using a Monte Carlo permutation test. Species are labeled with triangles. The closeness of these indicates correlation with each other and existence in similar environment. Environmental variables are showed by arrows; the relative length is positive correlation with the importance in influencing bacterial community structure. The angle between the arrow and the ordination axis suggests the variable response with respect to the RDA gradient. The two axes explain $65.9 \%$ of the variability. For bacteria, major ions in cloud water seem to be the crucial environmental variable in shaping community structure.

dispersal pathway for some pathogenic bacteria. Studies of the airborne dispersal of pathogenic bacteria, e.g., Neisseria meningitides, Staphylococcus aureus from dust samples from Kuwait, and Pseudomonas aeruginosa in the US Virgin Islands have indicated the spread of specific human and plant diseases over long-range transport in the atmosphere (Griffin, 2007; Griffin et al., 2003, 2006). However, detailed healthrisk-oriented studies on pathogenic microorganisms should be conducted in depth and prudently assessed. Further study depending on the culture-dependent method and biochemical experiments will perform to check the pathogenicity.

\subsection{Disparity between polluted and non-polluted cloud episodes}

To distinguish indicator species within the polluted and non-polluted cloud episodes, LEfSe was performed, which showed statistically significant differences. A total of 70 bacterial groups were distinct using the default logarithmic (LDA - linear discriminant analysis) value of 2. Cladograms show taxa with LDA values higher than 3.5 for clarity (Fig. 4). Consequently, 8 and 19 representative bacterial taxa are detected in polluted and non-polluted cloud episodes.

In polluted cloud episodes, most enriched bacteria were ranked as opportunistic pathogens, such as Proteobacte- ria, Gammaproteobacteria, Xanthomonadales, Xanthomonadaceae, Stenotrophomonas, Moraxellaceae, and Acinetobacter. Like Proteobacteria, the Gram-negative Gammaproteobacteria contains a series of ecologically and medically important bacteria, e.g., the pathogenic Enterobacteriaceae, Vibrionaceae, and Pseudomonadaceae. The Xanthomonadales from this phylum has been reported to cause disease in plants (Saddler and Bradbury, 2005). Certain species from Stenotrophomonas (Gammaproteobacteria, Xanthomonadales) are associated with multiple human infections. Moraxella from Moraxellaceae (Gammaproteobacteria) have been reported to be associated with septic arthritis of the ankle (Banks et al., 2007). As previously mentioned, species from the genus of Acinetobacter are opportunistic pathogens and cause severe clinical infections (Nemec et al., 2001).

In comparison, the majority of indicator species in the nonpolluted samples are from Bacteroidetes, Firmicutes, Betaproteobacteria, and Deinococcus-Thermus. An important biomarker from Bacteroidetes was Flavobacteriia. Comparative study has illustrated the marine sources for Flavobacteria. Most of Flavobacteria sequences searched for against the NCBI database using BLAST (Basic Local Alignment Search Tool) are mainly from marine sources, i.e., algae, oys- 


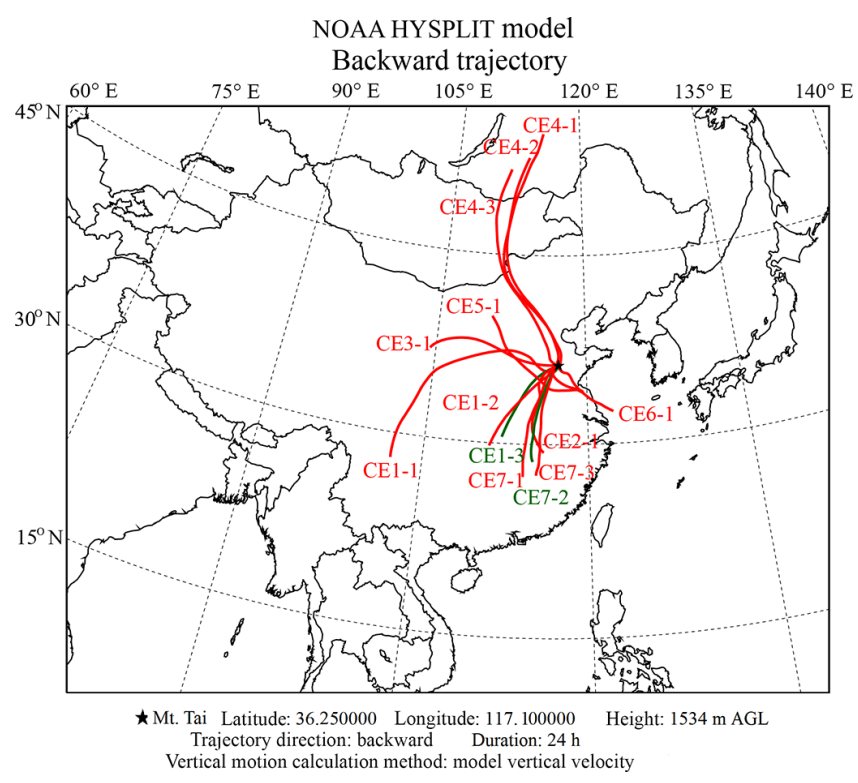

Figure 6. Air mass transport pathways for the cloud episodes using the Hybrid Single Particle Lagrangian Integrated Trajectory (HYSPLIT) model. $24 \mathrm{~h}$ backward trajectories were calculated for air parcels arriving at the summit of Mt Tai $\left(36^{\circ} 15^{\prime} \mathrm{N}, 117^{\circ} 06^{\prime} \mathrm{E}\right.$; 1534 m a.s.1.). CE refers to cloud episodes. The polluted episodes are indicated by red lines, and green lines are non-polluted episodes.

ters, and sea cucumbers (Cho and Jang, 2014). The genus Empedobacter was abundant across all samples, and they are included in the family Flavobacteriaceae. As mentioned above, Empedobacter are potential pathogens and resistant to a wide range of antimicrobials (Hugo et al., 2005). Clostridiales (Clostridia) and Bacillus (Bacillaceae) are two represent biomarkers from Firmicutes. Ubiquitous in nature, these two groups contain some medically significant species (Miller et al., 2001; Makino and Cheun, 2003). Moreover, their specific physiological characteristics (they produce a variety of enzymes and metabolites) and excellent ability to decompose organic matter mean that they been widely utilized in biotechnology and in the fermentation industry (Doi and Mcgloughlin, 1992; Łoś, et al., 2010). Members of Oxalobacteraceae (Betaproteobacteria) are rhizosphere microorganisms involved in biological nitrogen fixation (Donn et al., 2015). The Burkholderiales (Betaproteobacteria) commonly found in water and soil are involved in the biodegradation of various aromatic compounds (Pérez-Pantoja et al., 2012). Deinococci, from the phylum of DeinococcusThermus, could resist extreme radiation and survive in extremes of heat and cold (Griffiths and Gupta, 2007).

By comparison, potential pathogens were significant groups in the polluted samples, whereas diverse ecological function groups were identified in the non-polluted samples originating from a wide range of habitats. An ecologically meaningful distinction of bacterial groups under polluted and non-polluted conditions is essential for an understanding of the variation of bacterial community structure and function, which reveals the community dynamics under pollution stress.

\subsection{Environmental factors shaping the bacterial community structure}

To clarity the vital environmental factors shaping the bacterial community structure, RDA was performed to discern the genus-level structure with the selected environmental factors (Fig. 5). The first two axes explained $65.9 \%$ of the accumulated variance in the species-environment relation. Interset correlations showed major ions, and $\mathrm{PM}_{2.5}$ was the most important environmental variable structuring the bacterial community (axis 1, major ions, $-0.436 ; \mathrm{PM}_{2.5},-0.367$ ); in turn, wind speed and temperature registered a high value for axis 2 (wind speed, -0.509 ; temperature, -0.494 ; Table S1).

Cumulative fit indicated that the predominant genera affiliated with Acinetobacter, Bacillus, Corynebacterium, Phyllobacterium, Pseudoalteromonas, and Rhodococcus displayed strong correlations with axis 1. Empedobacter, Hydrotalea, Paracoccus, Pelomonas, Pseudomonas, and Stenotrophomonas were notable genera with high correlations with axis 2 (Table S2). As mentioned above in section 3.3 , the above bacteria were metabolically diverse groups found in various habitats and certain genera included potential pathogens.

Of the environmental characteristics measured, major ions in cloud water and $\mathrm{PM}_{2.5}$ were the crucial predictors of diversity variability of bacterial community structure. These two parameters were strongly correlated with the representative bacterial genera. As indicated in Fig. S1, significant positive correlation was observed between major ions $(x)$ and $\mathrm{PM}_{2.5}$ $\left(y ; y=0.00477 x+5.324, p<0.01 R^{2}=0.757\right)$. Relevant studies suggested that the bacterial community was highly variable under different $\mathrm{PM}_{2.5}$ mass concentrations (Cao et al., 2014). Statistical analysis, e.g., correlation or multiple linear regression, indicated that $\mathrm{PM}_{2.5}$ exhibited a negative correlation with airborne bacteria on haze days (Gandolfi et al., 2015; Gao et al., 2015), whereas in another study, Spearman correlation analysis showed that $\mathrm{PM}_{2.5}$ exhibited a significant positive correlation with the airborne microbe concentration (Dong et al., 2016). Possibly, the inorganic and organic compounds in particulate matter $\left(\mathrm{PM}_{2.5}\right)$ can be available nutrients for microbial growth in air. However, the aggregation of harmful substances such as heavy metals and polycyclic aromatic hydrocarbons under high $\mathrm{PM}_{2.5}$ mass concentration would be toxic for bacteria.

During cloud processes, most atmospheric particles (including $\mathrm{PM}_{2.5}$ ) are scavenged in cloud water. In polluted air, high $\mathrm{PM}_{2.5}$ concentration resulted in elevated water-soluble inorganic ions in cloud droplets. Therefore, similar trends were observed between major ions and $\mathrm{PM}_{2.5}$ concentration. In cloud water, the major water-soluble ions and microorgan- 


\section{(a) Polluted cloud episodes}

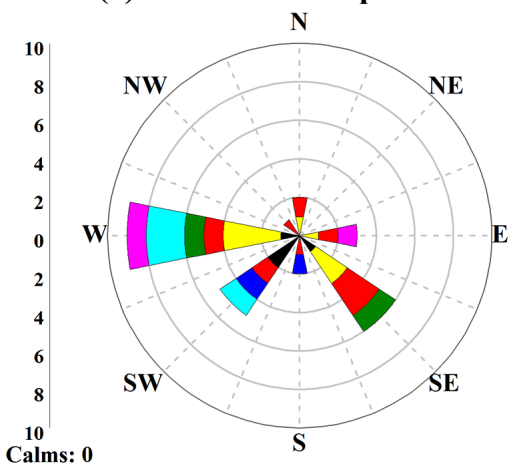

(b) Non-polluted cloud episodes
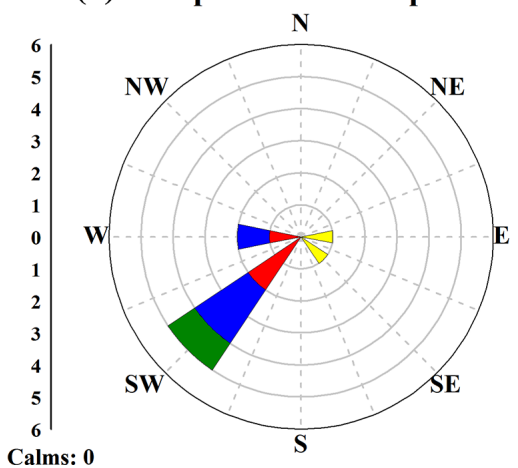
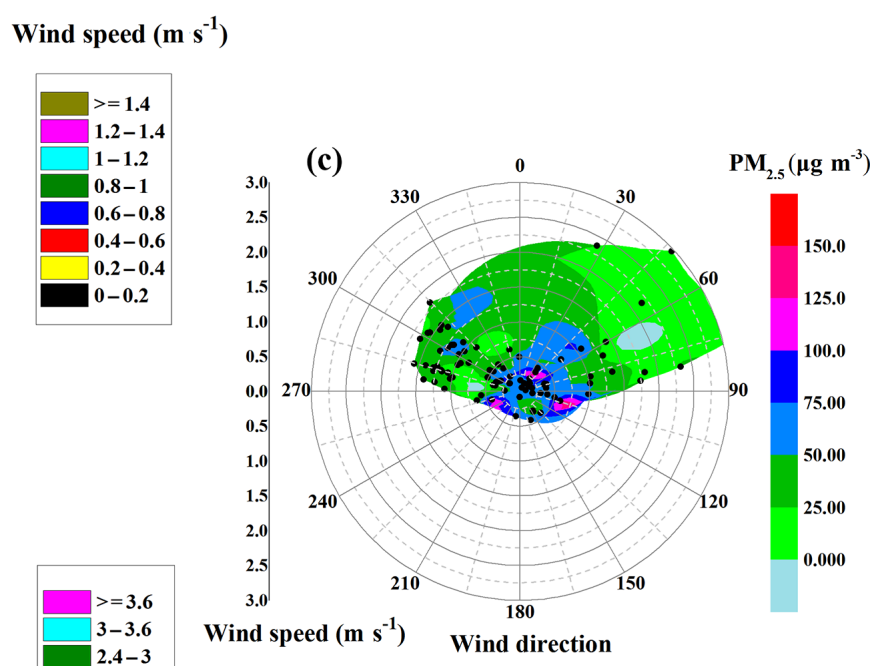

Figure 7. Wind rose diagram to quantitative analyze wind speed and wind direction during sampling time between polluted (a) and nonpolluted (b) cloud episodes. The frequency of winds is indicated by wind direction. Wind speed range is labeled with color bands. Wind direction with the greatest frequency is shown by the direction of the longest spoke. Panel (c) shows distribution of wind speed during the whole sampling time (from 24 July to 23 August 2014) and the correlation with $\mathrm{PM}_{2.5}$ concentration. As shown in the figure, $\mathrm{PM}_{2.5}$ concentration was high under lower wind speed, whereas $\mathrm{PM}_{2.5}$ was lower when wind speed was high.

isms coexist in the same microenvironment. Major ions could provide available nutrition for bacterial growth and duplication. A previous study has suggested that these nutrients are related to the distribution of bacteria in water habitats (Newton et al., 2011). Meanwhile, PICRUSt analysis in Sect. 3.2 discovered a series of metabolic pathways involved in basic bacterial physiological activities and the carbon, nitrogen, and sulfur metabolism (Fig. S6). For example, magnesium and calcium are involved in a series of physiological activities (e.g., signal regulation, transmembrane transport); sulfate, nitrate, and ammonium can be available substrates for bacterial growth (Fagerbakke, et al., 1999; Fiermonte, et al., 2004; Michiels et al., 2002). Therefore, major ions were important environmental factors shaping community structure in cloud water. $\mathrm{PM}_{2.5}$ played an indirect role in the bacterial community by influencing the concentration of major ions in water droplets.

The identified taxa from either polluted or non-polluted samples were typically found in soil, water, plants, or human beings. These bacterial groups aerosolized and dispersed into atmosphere either from local regional emissions or longrange transport. Source tracking analysis by backward trajectory indicated that the air mass of polluted cloud episodes came largely from northern and western China, moving east through Shanxi, Henan, and Hebei province to the study area, or from outer Mongolia, crossing the Jingjinji area to Mt Tai (Fig. 6). The areas passed were notable heavy industry regions with frequent coal mining activities and serious pollution. Moreover, the large population and agricultural activities resulted in numerous pathogenic microorganisms from human or animal fecal matter being dispersed in air. In contrast, air mass of non-polluted cloud episodes originated mostly from southern China, and the regions passed were rich in water resources, e.g., Dongting Hu, Huai He, Yangtze river. The marine-source bacteria (Flavobacteria, significant biomarker in non-polluted cloud water samples by LefSE, Fig. 4) dispersed in the atmosphere typically derived from the evaporation of lake and river water. These bacteria mainly originated from sea-air interactions, and the marine bacteria can be transported inland through long-range transport.

At the sampling site (the summit of Mt Tai, 1534 m a.s.1.), local anthropogenic pollution might be minimized and air pollution is mainly influenced by long-range transport. The wind rose diagram suggests a prevailing west wind during polluted cloud episodes, and wind speeds ranged from 1.2 to $1.4 \mathrm{~m} \mathrm{~s}^{-1}$, whereas during non-polluted cloud episodes 
it was mainly a southwest wind with a higher wind speed (2.4-3 $\mathrm{m} \mathrm{s}^{-1}$; Fig. 7). Wind direction and speed are important meteorological factors influencing fog/cloud formation (Fu et al., 2014). Recent studies also indicate that the variation of bacterial concentration and community structure conducted by wind (Evans et al., 2006; Jones and Harrison, 2004). In addition, the wind and $\mathrm{PM}_{2.5}$ distribution graph during the whole sampling time (from 24 July to 23 August 2014; Fig. 7c) indicates that the $\mathrm{PM}_{2.5}$ concentration was high under low wind speed, whereas $\mathrm{PM}_{2.5}$ was lower with high wind speed. Air mass from the contaminated area through long-range transport combined with lower wind speeds largely reduced the diffusion rate of pollutants and thus led to the sustained high $\mathrm{PM}_{2.5}$ during polluted cloud episodes. In polluted air, the soluble component in $\mathrm{PM}_{2.5}$ was accumulated in the atmosphere and could be dissolved in cloud water droplets during wet deposition. Therefore, the concentration of water-soluble ions increased under high $\mathrm{PM}_{2.5}$ concentration, which has a direct influence on the microbial community. Whereas in the non-polluted cloud episodes, higher wind speed was beneficial to the diffusion of pollutants and resulted in lower $\mathrm{PM}_{2.5}$ mass concentration, which finally led to the significant discrepancy of bacterial community structure. However, further research still needs to address the detailed interaction between bacterial community and environmental factors and to understand the mechanism of bacterial community response to chemical composition in clouds.

\section{Conclusions}

The composition and potential function of microbial communities in the atmospheric water phase (fog and clouds) remains rarely studied. Using $16 \mathrm{~S}$ rRNA gene sequencing, this study has presented a comprehensive investigation of bacterial ecological diversity during polluted and non-polluted cloud episodes and revealed a highly diverse bacterial community harbored in cloud water. Correlation analysis for the predominant genera and PICRUSt function predication enhanced our understanding of the distribution of bacteria and their potential involvement in the atmosphere, ecosystem, and human health. The identification of bacteria surviving in the poor-nutrition, low-temperature, and radiation environments encountered in fog/cloud water demonstrated bacterial activity in harsh atmospheric environments. They may act as efficient cloud condensation nuclei or ice nuclei, associated with biogeochemical cycling (nitrogen/carbon cycling), microbial degradation of organic compounds in fog/clouds, and the spread of specific human, animal, and plant diseases by potential pathogens. Moreover, community disparity between polluted and non-polluted cloud episodes suggested that major ions in cloud water seem to be pivotal in shaping bacterial communities. $\mathrm{PM}_{2.5}$ had a potential impact on bacterial community structure by influencing the major ions in water droplets, which is likely to provide a deep understanding of atmospheric microbial biodiversity under environmental stress. These results provide a basic understanding of the mechanism of bacterial community response and metabolism in polluted weather for further studies. However, due to limited sampling size and collected volume, the aforementioned focus needs further discussion. Continuous annual observation and culture-dependent experiments will be performed to target the detailed functions of the atmospheric bacterial community.

Data availability. The meteorological data are accessible at the China Meteorological Administration (http://www.cma.gov.cn/). Chemical properties of cloud water are available from the authors upon request (minwei@sdu.edu.cn). The back trajectory data from Hybrid Single Particle Lagrangian Integrated Trajectory (HYSPLIT) model are available at http://ready.arl.noaa.gov/HYSPLIT_ traj.php. The raw 16S rRNA gene sequences are available at the Sequence Read Archive (SRA) under accession number SRX1904235.

\section{The Supplement related to this article is available online at doi:10.5194/acp-17-5253-2017-supplement.}

Competing interests. The authors declare that they have no conflict of interest.

Acknowledgements. This work was supported by the National Natural Science Foundation of China (41605113, 41375126), the Taishan Scholar Grant (ts20120552), and the China Postdoctoral Science Foundation (no. 2015M582095).

Edited by: T. Zhu

Reviewed by: three anonymous referees

\section{References}

Abdelelhaleem, D.: Acinetobacter: environmental and biotechnological applications, Afr. J. Biotechnol., 4, 71-74, 2003.

Adhikari, A., Reponen, T., Grinshpun, S. A., Martuzevicius, D., and LeMasters, G.: Correlation of ambient inhalable bioaerosols with particulate matter and ozone: A two-year study, Environ. Pollut., 140, 16-28, 2006.

Ahern, H. E., Walsh, K. A., Hill, T. C. J., and Moffett, B. F.: Fluorescent pseudomonads isolated from Hebridean cloud and rain water produce biosurfactants but do not cause ice nucleation, Biogeosciences, 4, 115-124, doi:10.5194/bg-4-115-2007, 2007.

Aikawa, M., Hiraki, T., Shoga, M., and Tamaki, M.: Fog and precipitation chemistry at Mt Rokko in Kobe, April 1997-March 1998, Water Air Soil Poll., 130, 1517-1517, 2001.

Alavi, P., Starcher, M. R., Thallinger, G. G., Zachow, C., Müller, H., and Berg, G.: Stenotrophomonas comparative genomics reveals genes and functions that differentiate beneficial and pathogenic bacteria, BMC. Genomics., 15, 1-15, 2013. 
Amato, P., Ménager, M., Sancelme, M., Laj, P., Mailhot, G., and Delort, A.-M.: Microbial population in cloud water at the Puy de Dôme: Implications for the chemistry of clouds, Atmos. Environ., 39, 4143-4153, 2005.

Amato, P., Demeer, F., Melaouhi, A., Fontanella, S., Martin-Biesse, A.-S., Sancelme, M., Laj, P., and Delort, A.-M.: A fate for organic acids, formaldehyde and methanol in cloud water: their biotransformation by micro-organisms, Atmos. Chem. Phys., 7, 4159-4169, doi:10.5194/acp-7-4159-2007, 2007a.

Amato, P., Parazols, M., Sancelme, M., Laj, P., Mailhot, G., and Delort, A. M.: Microorganisms isolated from the water phase of tropospheric clouds at the Puy de Dome: major groups and growth abilities at low temperatures, FEMS Microbiol. Ecol., 59, 242254, 2007b.

Amato, P., Parazols, M., Sancelme, M., Mailhot, G., Laj, P., Delort, A.-M.: An important oceanic source of micro-organisms for cloud water at the Puy de Dôme (France), Atmos. Environ., 41, 8253-8263, 2007c.

Amato, P., Joly, M., Schaupp, C., Attard, E., Möhler, O., Morris, C. E., Brunet, Y., and Delort, A.-M.: Survival and ice nucleation activity of bacteria as aerosols in a cloud simulation chamber, Atmos. Chem. Phys., 15, 6455-6465, doi:10.5194/acp-15-64552015, 2015.

Anderson, M. J. and Willis, T. J.: Canonical analysis of principal coordinates: a useful method of constrained ordination for ecology, Ecology, 84, 511-525, 2008.

Andreae, M. O. and Rosenfeld, D.: Aerosol-cloud-precipitation interactions, Part 1. the nature and sources of cloud-active aerosols, Earth-Sci. Rev., 89, 13-41, doi:10.1016/j.earscirev.2008.03.001, 2008.

Badarinath, K. V. S., Latha, K. M., Chand, T. R. K., Reddy, R. R., Gopal, K. R., Reddy, L. S. S., Narasimhulu, K., and Kumar, K. R.: Black carbon aerosols and gaseous pollutants in an urban area in North India during a fog period, Atmos. Res., 85, 209-216, 2007.

Banks, L. N., Kurdy, N. M., Hassan, I., and Aster, A. S.: Septic arthritis of the ankle due to Moraxella osloensis, Foot. Ankle. Surg., 13, 189-191, 2007.

Bauer, H., Giebl, H., Hitzenberger, R., Anne, K. G., Georg, R., Franziska, Z., and Hans, P.: Airborne bacteria as cloud condensation nuclei, J. Geophys. Res., 108, 1919-1964, 2003.

Bell, S. G. and Wong, L. L.: P450 enzymes from the bacterium Novosphingobium aromaticivorans, Biochem. Bioph. Res. Co., 360, 666-672, 2007.

Ben Abdeljalil, N. O. and Vallance, J.: Biocontrol of rhizoctonia root rot in tomato and enhancement of plant growth using Rhizobacteria naturally associated to tomato, J. Plant. Pathol. Microbiol., 7, 356, doi:10.4172/2157-7471.1000356, 2016.

Bertolini, V., Gandolfi, I., Ambrosini, R., Bestetti, G., Innocente, E., Rampazzo, G., and Franzetti, A.: Temporal variability and effect of environmental variables on airborne bacterial communities in an urban area of Northern Italy, Appl. Microbiol. Biotechnol., 97, 6561-6570, 2013.

Bibby, K., Viau, E., and Peccia, J.: Pyrosequencing of the 16S rRNA gene to reveal bacterial pathogen diversity in biosolids, Water. Res., 44, 4252-4260, 2010.

Bock, C., Kroppenstedt, R. M., and Diekmann, H.: Degradation and bioconversion of aliphatic and aromatic hydrocarbons by
Rhodococcus ruber 219, Appl. Microbiol. Biot., 45, 408-410, 1996.

Boonchan, S., Britz, M. L., and Stanley, G. A.: Surfactant-enhanced biodegradation of high molecular weight polycyclic aromatic hydrocarbons by Stenotrophomonas maltophilia, Biotechnol. Bioeng., 59, 482-494, 1998.

Boris, A. J., Lee, T., Park, T., Choi, J., Seo, S. J., and Collett Jr., J. L.: Fog composition at Baengnyeong Island in the eastern Yellow Sea: detecting markers of aqueous atmospheric oxidations, Atmos. Chem. Phys., 16, 437-453, doi:10.5194/acp-16-437-2016, 2016.

Bottone, E. J., Madayag, R. M., and Qureshi, M. N.: Acanthamoeba keratitis: synergy between amebic and bacterial cocontaminants in contact lens care systems as a prelude to infection, J. Clin. Microbiol., 30, 2447-2450, 1992.

Bowers, R. M., Lauber, C. L., Wiedinmyer, C., Hamady, M., Hallar, A.G ., Fall, R., Knight, R., and Fierer, N.: Characterization of airborne microbial communities at a high-elevation site and their potential to act as atmospheric ice nuclei, Appl. Environ. Microbiol., 75, 5121-5130, 2009.

Bowers, R. M., Clements, N., Emerson, J. B., Wiedinmyer, C., Hannigan, M. P., and Fierer, N.: Seasonal variability in bacterial and fungal diversity of the near-surface atmosphere, Environ. Sci. Technol., 47, 12097-12106, 2013.

Bozal, N., Montes, M. J., Tudela, E., and Guinea, J.: Characterization of several Psychrobacter strains isolated from Antarctic environments and description of Psychrobacter luti sp. nov. and Psychrobacter fozii sp. nov, Int. J. Syst. Evol. Micr., 53, 1093 1100, 2003.

Burrows, S. M., Elbert, W., Lawrence, M. G., and Pöschl, U.: Bacteria in the global atmosphere - Part 1: Review and synthesis of literature data for different ecosystems, Atmos. Chem. Phys., 9, 9263-9280, doi:10.5194/acp-9-9263-2009, 2009.

Busse, H., Denner, E., Buczolits, S., Salkinoja-Salonen, M., Bennasar, A., and Kämpfer, P.: Sphingomonas aurantiaca sp. nov., Sphingomonas aerolata sp. nov. and Sphingomonas faeni sp. nov., air- and dustborne and Antarctic, orange-pigmented, psychrotolerant bacteria, and emended description of the genus Sphingomonas, Int. J. Syst. Evol. Micr., 53, 1253-1260, 2003.

Cao, C., Jiang, W., Wang, B., Fang, J., Lang, J., Tian, G., Jiang, J., and Zhu, T. F.: Inhalable microorganisms in Beijing's PM $_{2.5}$ and $\mathrm{PM}_{10}$ pollutants during a severe smog event, Environ. Sci. Technol., 48, 1499-1507, 2014.

Cho, B. C. and Jang, G. I.: Active and diverse rainwater bacteria collected at an inland site in spring and summer 2011, Atmos. Environ., 94, 409-416, 2014.

Clarke, K. R.: Non-parametric multivariate analyses of changes in community structure, Aust. Ecol., 18, 117-143, 1993.

Corrigan, A., de Leeuw, M., Penaud-Frezet, S., Dimova, D., and Murphy, R. A.: Phylogenetic and functional alterations in bacterial community compositions in broiler ceca as a result of mannan oligosaccharide supplementation, Appl. Environ. Microbiol., 81, 3460-3470, 2015.

Creamean, J. M., Suski, K. J., Rosenfeld, D., Cazorla, A., Demott, P. J., and Sullivan, R. C., White, A. B., Ralph, F. M., Minnis, P., and Comstock, J. M.: Dust and biological aerosols from the Sahara and Asia influence precipitation in the western US, Science, 339, 1572-1578, 2013. 
Delort, A. M., Vaïtilingom, M., Amato, P., Sancelme, M., Parazols, M., Mailhot, G., Laj, P., and Deguillaume, L.: A short overview of the microbial population in clouds: potential roles in atmospheric chemistry and nucleation processes, Atmos. Res., 98, 249-260, 2010.

Després, V. R., Alex Huffman, J., Burrows, S. M., Hoose, C., Safatov, A. S., Buryak, G., Fröhlich-Nowoisky, J., Elbert, W., Andreae, M. O., Pöschl, U., and Jaenicke, R.: Primary biological aerosol particles in the atmosphere: a review, Tellus B, 64, 145$153,2012$.

Doi, R. H. and Mcgloughlin, M.: Biology of Bacilli, Applications to industry, The Quarterly Review of Biology, 1992.

Dong, L., Qi, J., Shao, C., Zhong, X., Gao, D., Cao, W., Gao, J., Bai, R., Long, G., and Chu, C.: Concentration and size distribution of total airborne microbes in hazy and foggy weather, Sci. Total. Environ., 541, 1011-1018, 2016.

Donn, S., Kirkegaard, J. A., Perera, G., Richardson, A. E., and Watt, M.: Evolution of bacterial communities in the wheat crop rhizosphere, Environ. Microbiol., 17, 610-621, 2015.

Ehrenhauser, F. S., Khadapkar, K., Wang, Y., Hutchings, J. W., Delhomme, O., Kommalapati, R. R., Herckes, P., Wornat, M. J., and Valsaraj, K. T.: Processing of atmospheric polycyclic aromatic hydrocarbons by fog in an urban environment, J. Environ. Monitor., 14, 2566-2579, 2012.

Evans, C. A., Coombes, P. J., and Dunstan, R. H.: Wind, rain and bacteria: the effect of weather on the microbial composition of roof-harvested rainwater, Water. Res., 40, 37-44, 2006.

Fagerbakke, K. M., Norland, S., and Heldal, M.: The inorganic ion content of native aquatic bacteria, Can. J. Microbiol., 45, 304311, 1999.

Fernández-González, R., Yebra-Pimentel, I., Martínez-Carballo, E., Simal-Gándara, J., and Pontevedra-Pombal, X.: Atmospheric pollutants in fog and rain events at the northwestern mountains of the Iberian Peninsula, Sci. Total. Environ., 497-498, 188-199, 2014.

Fiermonte, G., Leonardis, F. D., Todisco, S., Palmieri, L., Lasorsa, F. M., and Palmieri, F.: Identification of the mitochondrial ATP-Mg/Pi transporter, Bacterial expression, reconstitution, functional characterization, and tissue distribution, J. Biol. Chem., 279, 30722-30730, 2004.

Fu, G. Q., Xu, W. Y., Yang, R. F., Li, J. B., and Zhao, C. S.: The distribution and trends of fog and haze in the North China Plain over the past 30 years, Atmos. Chem. Phys., 14, 11949-11958, doi:10.5194/acp-14-11949-2014, 2014.

Fuzzi, S., Mandrioli, P., and Perfetto, A.: Fog droplets - an atmospheric source of secondary biological aerosol particles, Atmos. Environ., 31, 287-290, 1997.

Gallego, V., García, M. T., and Ventosa, A.: Methylobacterium hispanicum sp. nov. and Methylobacterium aquaticum sp. nov., isolated from drinking water, Int. J. Syst. Evol. Micr., 55, 281-287, 2005.

Gallego, V., García, M. T., and Ventosa, A.: Methylobacterium adhaesivum sp. nov., a methylotrophic bacterium isolated from drinking water, Int. J. Syst. Evol. Micr., 56, 339-342, 2006.

Gandhi, P. M., Narayanan, K. B., Naik, P. R., and Sakthivel, N.: Characterization of chryseobacterium aquaticum strain PUPC1 producing a novel antifungal protease from rice rhizosphere soil, J. Microbiol. Biotechn., 19, 99-107, 2009.
Gandolfi, I., Bertolini, V., Bestetti, G., Ambrosini, R., Innocente, E., Rampazzo, G., Papacchini, M., and Franzetti, A.: Spatiotemporal variability of airborne bacterial communities and their correlation with particulate matter chemical composition across two urban areas, Appl. Microbiol. Biot., 99, 4867-4877, 2015.

Gao, M., Qiu, T., Jia, R., Han, M., Song, Y., and Wang, X.: Concentration and size distribution of viable bioaerosols during nonhaze and haze days in Beijing, Environ. Sci. Pollut. R., 22, 43594368, 2015.

Gao, M., Yan, X., Qiu, T., Han, M., and Wang, X.: Variation of correlations between factors and culturable airborne bacteria and fungi, Atmos. Environ., 128, 10-19, 2016.

Geng, L., Ming, C., Liang, Q., Wei, L., Wei, Z., Ping, S., Wei, L., Yan, Y., Wang, W., and Takeo, M.: Functional analysis of a putative regulatory gene, tadR, involved in aniline degradation in Delftia tsuruhatensis AD9, Arch. Microbiol., 191, 603-614, 2009.

Gilad, J., Borer, A., Peled, N., Riesenberg, K., Tager, S., Appelbaum, A., and Schlaeffer, F.: Hospital-acquired brevundimonas vesicularis septicaemia following open-heart surgery: case report and literature review, Infect. Dis., 32, 90-91, 2009.

Glaeser, S. P. and Kämpfer, P.: The Family Sphingomonadaceae, Springer, Berlin, Heidelberg, 2014.

Gonzalezbashan, L. E., Lebsky, V. K., Hernandez, J. P., Bustillos, J. J., and Bashan, Y.: Changes in the metabolism of the microalga Chlorella vulgaris when coimmobilized in alginate with the nitrogen-fixing Phyllobacterium myrsinacearum, Can. J. Microbiol., 46, 653-659, 2000.

Gopalakrishnan, S., Srinivas, V., Prakash, B., Sathya, A., and Vijayabharathi, R.: Plant growth-promoting traits of Pseudomonas geniculata isolated from chickpea nodules, 3 Biotech, 5, 653661, 2015.

Goyal, A. K. and Zylstra, G. J.: Molecular cloning of novel genes for polycyclic aromatic hydrocarbon degradation from Comamonas testosteroni GZ39, Appl. Environ. Microbiol., 62, 230236, 1996.

Griffin, D. W.: Atmospheric movement of microorganisms in clouds of desert dust and implications for human health, Clin. Microbiol. Rev., 20, 459-477, 2007.

Griffin, D. W., Kellogg, C. A., Garrison, V. H., Lisle, J. T., Borden, T. C., and Shinn, E. A.: Atmospheric microbiology in the northern Caribbean during African dust events, Aerobiologia, 19, 143-157, 2003.

Griffin, D. W., Westphal, D. L., and Gray, M. A.: Airborne microorganisms in the African desert dust corridor over the mid-Atlantic ridge, Ocean Drilling Program, Leg 209, Aerobiologia, 22, 211 226, 2006.

Griffiths, E. and Gupta, R. S.: Identification of signature proteins that are distinctive of the Deinococcus-Thermus phylum, Int. Microbiol., 10, 201-208, 2007.

Guo, F. and Zhang, T.: Profiling bulking and foaming bacteria in activated sludge by high throughput sequencing, Water. Res., 46, 2772-2782, 2012.

Guo, J., Wang, Y., Shen, X., Wang, Z., Lee, T., Wang, X., Li, P., Sun, M., Collett Jr., J. L., Wang, W., and Wang, T.: Characterization of cloud water chemistry at Mount Tai, China: seasonal variation, anthropogenic impact, and cloud processing, Atmos. Environ., 60, 467-476, 2012. 
Hackney, J. D., Linn, W. S., and Avol, E. L.: Acid fog: effects on respiratory function and symptoms in healthy and asthmatic volunteers, Environ. Health Persp., 79, 159-162, 1989.

Han, X. Y. and Andrade, R. A.: Brevundimonas diminuta infections and its resistance to fluoroquinolones, J. Antimicrob. Chemoth., 55, 853-859, 2005.

Hauser, E., Kämpfer, P., and Busse, H. J.: Pseudomonas psychrotolerans sp. nov, Int. J. Syst. Evol. Micr., 54, 1633-1637, 2004.

Hill, K. A., Shepson, P. B., Galbavy, E. S., Anastasio, C., Kourtev, P.S ., Konopka, A., and Stirm, B. H.: Processing of atmospheric nitrogen by clouds above a forest environment, J. Geophys. Res., 112, 2864-2864, 2007.

Huang, K., Zhuang, G., Wang, Q., Fu, J. S., Lin, Y., Liu, T., Han, L., and Deng, C.: Extreme haze pollution in Beijing during January 2013: chemical characteristics, formation mechanism and role of fog processing, Atmos. Chem. Phys. Discuss., 14, 7517-7556, doi:10.5194/acpd-14-7517-2014, 2014.

Hugo, C. J., Bruun, B., and Jooste, P. J.: The Genera Empedobacter and Myroides, Springer New York, 630-637, 2005.

Jha, M. N., Prasad, A. N., and Misra, S. K.: Influence of source of organics and soil organic matter content on cyanobacterial nitrogen fixation and distributional pattern under different water regimes, World. J. Microb. Biot., 20, 673-677, 2004.

Joly, M., Attard, E., Sancelme, M., Deguillaume, L., Guilbaud, C., Morris, C. E., Amato, P., and Delort, A.-M.: Ice nucleation activity of bacteria isolated from cloud water, Atmos. Environ., 70, 392-400, 2013.

Jones, A. M. and Harrison, R. M.: The effects of meteorological factors on atmospheric bioaerosol concentrations-a review, Sci. Total. Environ., 326, 151-180, 2004.

Kämpfer, P., Lodders, N., Huber, B., Falsen, E., and Busse, H. J.: Deinococcus aquatilis sp. nov., isolated from water, Int. J. Syst. Evol. Micr., 58, 2803-2806, 2009.

Katra, I., Arotsker, L., Krasnov, H., Zaritsky, A., Kushmaro, A., and Ben-Dov, E.: Richness and diversity in dust stormborne biomes at the southeast mediterranean, Sci. Rep., 4, 5265, doi:10.1038/srep05265, 2014.

Kaushik, R. and Balasubramanian, R.: Assessment of bacterial pathogens in fresh rainwater and airborne particulate matter using Real-Time PCR, Atmos. Environ., 46, 131-139, 2012.

Kindt, R. and Coe, R.: Tree diversity analysis: a manual and software for common statistical methods for ecological and biodiversity studies, J. Am. Vet. Med. A., 235, 368-374, 2005.

Kopcakova, A., Stramova, Z., Kvasnova, S., Godany, A., Perhacova, Z., and Pristas, P.: Need for database extension for reliable identification of bacteria from extreme environments using MALDI TOF mass spectrometry, Chem. Pap., 68, 1435-1442, 2014.

Kourtev, P. S., Hill, K. A., Shepson, P. B., and Konopka, A.: Atmospheric cloud water contains a diverse bacterial community, Atmos. Environ., 45, 5399-5405, 2011.

Kuczynski, J., Stombaugh, J., Walters, W.A., González, A., Caporaso, J. G., and Knight, R.: Using QIIME to analyze 16S rRNA gene sequences from microbial communities:current protocols in microbiology, Curr. Protoc. Bioinformatics, 10, 1-28, 2011.

Langille, M. G., Zaneveld, J., Caporaso, J. G., McDonald, D., Knights, D., Reyes, J. A., Clemente, J. C., Burkepile, D. E., Vega Thurber, R. L., Knight, R., Beiko, R. G., and Huttenhower, C.: Predictive functional profiling of microbial communities using
16S rRNA marker gene sequences, Nat. Biotechnol., 31, 814821, 2013.

Liu, X. H., Wai, K. M., Wang, Y., Zhou, J., Li, P. H., Guo, J., Xu, P. J., and Wang, W. X.: Evaluation of trace elements contamination in cloud/fog water at an elevated mountain site in Northern China, Chemosphere, 88, 531-41, 2012.

Liu, Y., Wang, L., Huang, K., Wang, W., Nie, X., Jiang, Y., Li, P., Liu, S., Xu, P., and Tang, H.: Physiological and biochemical characterization of a novel nicotine-degrading bacterium Pseudomonas geniculata N1, Plos One, 9, 393-418, 2014.

Łoś, M., Kuzio, J., Mcconnell, M. R., Kropinski, A. M., Węgrzyn, G. and Christie, G. E.: Lysogenic conversion in bacteria of importance to the food industry, ASM Press, Washington, 157-198, doi:10.1128/9781555816629.ch9, 2010.

Luo, G. and Angelidaki, I.: Analysis of bacterial communities and bacterial pathogens in a biogas plant by the combination of ethidium monoazide, PCR and Ion Torrent sequencing, Water. Res., 60, 156-163, 2014.

Madsen, A. M., Zervas, A., Tendal, K., and Nielsen, J. L.: Microbial diversity in bioaerosol samples causing ODTS compared to reference bioaerosol samples as measured using Illumina sequencing and MALDI-TOF, Environ. Res., 140, 255-267, 2015.

Makino, S.-I. and Cheun, H.-I.: Application of the real-time PCR for the detection of airborne microbial pathogens in reference to the anthrax spores, J. Microbiol. Meth., 53, 141-147, 2003.

Masoud, W., Takamiya, M., Vogensen, F. K., Lillevang, S., AlSoud, W. A., Sørensen, S. J., and Jakobsen, M.: Characterization of bacterial populations in Danish raw milk cheeses made with different starter cultures by denaturating gradient gel electrophoresis and pyrosequencing, Int. Dairy. J., 21, 142-148, 2011.

Mattimore, V. and Battista, J. R.: Radioresistance of Deinococcus radiodurans: functions necessary to survive ionizing radiation are also necessary to survive prolonged desiccation, J. Bacteriol., 178, 633-637, 1996.

Meziane, H., Sluis, I. V. D., Loon, L. C. V., Höfte, M., and Bakker, P. A. H. M.: Determinants of Pseudomonas putida WCS358 involved in inducing systemic resistance in plants, Mol. Plant. Pathol., 6, 177-185, 2005.

Michiels, J., Xi, C., Verhaert, J., and Vanderleyden, J.: The functions of $\mathrm{Ca}^{2+}$ in bacteria: a role for EF-hand proteins?, Trends. Microbiol., 10, 87-93, 2002.

Miller, D. L., Brazer, S., Murdoch, D., Reller, L. B., and Corey, G. R.: Significance of Clostridium tertium bacteremia in neutropenic and nonneutropenic patients: review of 32 cases, Clin. Infect. Dis., 32, 975-978, 2001.

Mohan, M. and Payra, S.: Influence of aerosol spectrum and air pollutants on fog formation in urban environment of megacity Delhi, India, Environ. Monit. Assess., 151, 265-277, 2009.

Möhler, O., DeMott, P. J., Vali, G., and Levin, Z.: Microbiology and atmospheric processes: the role of biological particles in cloud physics, Biogeosciences, 4, 1059-1071, doi:10.5194/bg-4-10592007, 2007.

Mortazavi, R., Hayes, C. T., and Ariya, P. A.: Ice nucleation activity of bacteria isolated from snow compared with organic and inorganic substrates, Environ. Chem., 5, 373-381, 2008.

Mortazavi, R., Attiya, S., and Ariya, P. A.: Arctic microbial and next-generation sequencing approach for bacteria in snow and frost flowers: selected identification, abundance and freezing nu- 
cleation, Atmos. Chem. Phys., 15, 6183-6204, doi:10.5194/acp15-6183-2015, 2015.

Nakamura, S., Sakamoto, Y., Ishiyama, M., Tanaka, D., Kunii, K., Kubo, K., and Sato, C.: Characterization of two oil-degrading bacterial groups in the Nakhodka oil spill, Int. Biodeter. Biodegr., 60, 202-207, 2007.

Nemec, A., De Baere, T., Tjernberg, I., Vaneechoutte, M., van der Reijden, T. J., and Dijkshoorn, L.: Acinetobacter ursingii sp. nov. and Acinetobacter schindleri sp. nov., isolated from human clinical specimens, Int. J. Syst. Evol. Micr., 51, 1891-1899, 2001.

Newton, R. J., Jones, S. E., Alexander, E., Mcmahon, K. D., and Stefan, B.: A guide to the natural history of freshwater lake bacteria, Microbiol. Mol. Biol. R., 75, 14-49, 2011.

Nováková, D., Sedlácek, I., Pantůcek, R., Stetina, V., Svec, P., and Petrás, P.: Staphylococcus equorum and Staphylococcus succinus isolated from human clinical specimens, J. Med. Microbiol., 55, 523-528, 2006.

Pérez-Pantoja, D., Donoso, R., Agulló, L., Córdova, M., Seeger, M., Pieper, D. H., eand González, B.: Genomic analysis of the potential for aromatic compounds biodegradation in Burkholderiales, Environ. Microbiol., 14, 1091-1117, 2012.

Pöschl, U.: Atmospheric aerosols: composition, transformation, climate and health effects, Angew. Chem. Int. Edit., 37, 7520-7540, 2006.

Ponder, M. A., Gilmour, S. J., Bergholz, P. W., Mindock, C. A., Hollingsworth, R., Thomashow, M. F., and Tiedje, J. M.: Characterization of potential stress responses in ancient Siberian permafrost psychroactive bacteria, FEMS Microbiol. Ecol., 53, 103$115,2005$.

Reardon, K. F., Mosteller, D. C., and Bull Rogers, J. D.: Biodegradation kinetics of benzene, toluene, and phenol as single and mixed substrates for Pseudomonas putida F1, Biotechnol. Bioeng., 69, 385-400, 2000.

Saddler, G. S. and Bradbury, J. F.: Xanthomonadales ord. nov, in: Bergey's Manual of Systematic Bacteriology, Springer US, 63122, 2005.

Schloss, P., Westcott, S., Ryabin, T., Hall, J., Hartmann, M., Hollister, E., Lesniewski, R., Oakley, B., Parks, D., and Robinson, C.: Introducing mothur: open-source, platform-independent, community-supported software for describing and comparing microbial communities, Appl. Environ. Microbiol., 75, 75377541, 2009.

Segata, N., Izard, J., Waldron, L., Gevers, D., Miropolsky, L., Garrett, W. S., and Huttenhower, C.: Metagenomic biomarker discovery and explanation, Genome. Biol., 12, 1-18, 2011.
Seo, Y. S., Lee, D. Y., Rayamahji, N., Mi, L. K., and Han, S. Y.: Biofilm-forming associated genotypic and phenotypic characteristics of Staphylococcus spp. isolated from animals and air, Res. Vet. Sci., 85, 433-438, 2008.

Simmons, G., Hope, V., Lewis, G., Whitmore, J., and Gao, W.: Contamination of potable roof-collected rainwater in Auckland, New Zealand, Water. Res., 35, 1518-1524, 2001.

Stanier, R. Y., Palleroni, N. J., and Doudoroff, M.: The aerobic pseudomonads: a taxonomic study, J. Gen. Microbiol., 43, 159-271, 2010.

Vaittilingom, M., Amato, P., Sancelme, M., Laj, P., Leriche, M., and Delort, A. M.: Contribution of microbial activity to carbon chemistry in clouds, Appl. Environ. Microbiol., 76, 23-29, 2010.

Vaitilingom, M., Attard, E., Gaiani, N., Sancelme, M., Deguillaume, L., Flossmann, A. I., Amato, P., and Delort, A.-M.: Long-term features of cloud microbiology at the puy de Dôme (France), Atmos. Environ., 56, 88-100, 2012.

Vaïtilingom, M., Deguillaume, L., Vinatier, V., Sancelme, M., Amato, P., Chaumerliac, N., and Delort, A.-M.: Potential impact of microbial activity on the oxidant capacity and organic carbon budget in clouds, P. Natl. Acad. Sci. USA, 110, 559-564, 2013.

Wang, X., Chen, J., Sun, J., Li, W., Yang, L., Wen, L., Wang, W., Collett, J. L., Jr, Shi, Y., Zhang, Q., Hu, J., Yao, L., Zhu, Y., Sui, X., Sun, X., and Mellouki, A.: Severe haze episodes and seriously polluted fog water in Ji'nan, China, Sci. Total. Environ., 493, 133-137, 2014.

Wolf, A., Fritze, A., Hagemann, M., and Berg, G.: Stenotrophomonas rhizophila sp. nov., a novel plant-associated bacterium with antifungal properties, Int. J. Syst. Evol. Micr., 52, 1937-1944, 2002.

Womack, A. M., Bohannan, B. J., and Green, J. L.: Biodiversity and biogeography of the atmosphere, Philos. T. R. Soc. B, 365, 3645-3653, 2010

Wu, J., Peters, B. A., Dominianni, C., Zhang, Y., Pei, Z., Yang, L., Ma, Y., Purdue, M. P., Jacobs, E. J., Gapstur, S. M., Li, H., Alekseyenko, A. V., Hayes, R. B., and Ahn, J.: Cigarette smoking and the oral microbiome in a large study of American adults, ISME J., 10, 2435-2446, 2016.

Xu, P., Yu, B., Li, F. L., Cai, X. F., and Ma, C. Q.: Microbial degradation of sulfur, nitrogen and oxygen heterocycles, Trends Microbiol., 14, 398-405, 2006. 